\title{
Risk factors associated with sustained circulation of six zoonotic arboviruses: a systematic review for selection of surveillance sites in non-endemic areas
}

\author{
Helen J. Esser ${ }^{1,2^{*}+}$ (C, Ramona Mögling ${ }^{3 \dagger}$, Natalie B. Cleton ${ }^{3,4}$, Henk van der Jeugd ${ }^{5}$, Hein Sprong ${ }^{4}$, Arjan Stroo $^{6}$,
} Marion P. G. Koopmans ${ }^{3}$, Willem F. de Boer ${ }^{1 \neq}$ and Chantal B. E. M. Reusken ${ }^{3,4 \neq}$

\begin{abstract}
Arboviruses represent a significant burden to public health and local economies due to their ability to cause unpredictable and widespread epidemics. To maximize early detection of arbovirus emergence in non-endemic areas, surveillance efforts should target areas where circulation is most likely. However, identifying such hotspots of potential emergence is a major challenge. The ecological conditions leading to arbovirus outbreaks are shaped by complex interactions between the virus, its vertebrate hosts, arthropod vector, and abiotic environment that are often poorly understood. Here, we systematically review the ecological risk factors associated with the circulation of six arboviruses that are of considerable concern to northwestern Europe. These include three mosquito-borne viruses (Japanese encephalitis virus, West Nile virus, Rift Valley fever virus) and three tick-borne viruses (Crimean-Congo hemorrhagic fever virus, tick-borne encephalitis virus, and louping-ill virus). We consider both intrinsic (e.g. vector and reservoir host competence) and extrinsic (e.g. temperature, precipitation, host densities, land use) risk factors, identify current knowledge gaps, and discuss future directions. Our systematic review provides baseline information for the identification of regions and habitats that have suitable ecological conditions for endemic circulation, and therefore may be used to target early warning surveillance programs aimed at detecting multi-virus and/or arbovirus emergence.
\end{abstract}

Keywords: West Nile virus, Japanese encephalitis virus, Rift Valley fever virus, Tick-borne encephalitis virus, Louping-ill virus, Crimean-Congo hemorrhagic fever virus

\section{Background}

The recent (re-)emergence of different arthropod-borne viruses in Europe has highlighted the fact that both novel and known arboviral diseases can infest and establish in previously naive areas [1]. Globalization, climate change, habitat modification, and increased human and animal populations and movement (e.g. host dispersal, migration, transport) are only some of the factors that have

\footnotetext{
*Correspondence: helen.esser@wur.nl

†Helen J. Esser and Ramona Mögling contributed equally to this work

‡Willem F. de Boer and Chantal B. E. M. Reusken are joint senior authors

${ }^{1}$ Resource Ecology Group, Wageningen University \& Research,

Wageningen, The Netherlands

Full list of author information is available at the end of the article
}

redefined the geographical distribution of arboviruses and their vectors, such as ticks and mosquitoes [2]. A recent example is the dengue epidemic in Madeira in 2012, where the establishment of the (sub)tropical mosquito vector Aedes aegypti facilitated a dengue outbreak upon introduction of the virus by a traveler returning from an endemic country [3]. Multiple examples of introduction and/or geographical expansion of arboviral diseases and their vectors in Europe underline the need for effective surveillance in high-risk areas to maximize early detection, a prerequisite for adequate risk management [4-10].

Identifying areas with endemic potential, and hence improving the selection of areas for surveillance, requires a thorough understanding of the ecological factors (both 
biotic and abiotic) that promote local virus circulation. Due to the nature of their transmission cycle, which involves specific arthropod vectors and vertebrate hosts, the epidemiology of arboviruses is complex and strongly influenced by environmental conditions and other aspects of vector and host ecology. Arboviruses like yellow fever virus, dengue virus and chikungunya virus even circulate in different ecological cycles (i.e. sylvatic and urban cycles) involving different vector and host species and driven by differences in ecological factors such as vector host preferences, local host abundances and herd immunity [11-14]. Vector survival and arbovirus replication are strongly influenced by climatic conditions such as temperature, humidity and precipitation, with vector activity and virus transmission often being seasonal [15]. Local vector abundance may further depend on the availability of specific breeding habitats, such as water bodies for mosquito oviposition [16], or specific vertebrate host species for feeding [17]. For example, many tick species have different host preferences at different life stages [18], and high host densities may greatly increase tick abundance [19]. Further, host migration enables dispersal of both ticks and arboviruses over long distances, often to novel areas $[17,20]$. Virus circulation is also influenced by the spatial and temporal variation in the densities of competent vertebrate reservoir hosts. Finally, the availability of suitable habitat and/or important host species is often correlated with particular land use categories, such as fragmented and highly mosaic agricultural landscapes [21]. However, despite recent advancements, our current understanding of the specific ecological factors that facilitate virus circulation and their relative impact thereon is limited for many arboviruses, and identification of areas of potential emergence therefore remains a challenge.

Here, we systematically review the ecological risk factors associated with the circulation of six arboviruses that are of considerable concern to northwestern Europe. Selection of these arboviruses was based on an earlier assessment of the risk of emerging zoonotic pathogens for public health in the Netherlands [22], and include the three top ranking mosquito-borne viruses, i.e. West Nile virus (WNV), Japanese encephalitis virus (JEV), Rift Valley fever virus (RVFV), and the three top-ranking tickborne viruses, i.e. tick-borne encephalitis virus (TBEV), louping-ill virus (LIV) and Crimean-Congo hemorrhagic fever virus (CCHFV). While some of these viruses are already endemic to parts of Europe (WNV, TBEV, LIV and (CHFV), their ranges have recently expanded and may continue to spread both northwards and to higher altitudes under projected changes in climate, land use, and vector and host distributions [8, 17, 23, 24]. In contrast, JEV and RVFV are not yet circulating in Europe, but the potential for their introduction $[25,26]$ and/ or the presence of putatively competent vectors $[27,28]$ in Europe merits further investigation. The results of our systematic review can be used for the identification of areas with the highest potential for virus introduction and establishment of circulation, thereby providing a rationale for targeted surveillance programs aimed at early detection of these arboviruses.

\section{Methods}

Data sources and search strategy

We performed a systematic literature search following the Preferred Reporting Items for Systematic Reviews and Meta-Analyses (PRISMA) guidelines [29] and Cochrane Collaboration guidelines [30]. We searched for peer-reviewed articles in PubMed and EMBASE databases (Table 1). We first screened potentially relevant records based on titles, abstracts and keywords and then read full-text articles to evaluate them according to our selection criteria.

\section{Selection criteria}

Studies were considered eligible if they met the following selection criteria: (i) studies focused on ecological variables that may promote virus circulation, including variables related to climate (e.g. precipitation, humidity, temperature), habitat (e.g. habitat fragmentation, Normalized Difference Vegetation Index), or vector and host ecology (e.g. population density, migration); (ii) studies reported only primary collected data or models; (iii) studies published between January 1st 1980 and January 7th 2016.

Reviews were excluded but all the data they reported were checked and compared to the results of our literature search. Any study that was identified in the reviews but not selected by our search was added to our review. Bibliographies of relevant articles and literature reviews were also cross-checked for potential relevant records. We used a data extraction pre-piloted form and entered the extracted data into an Excel database. Data published in multiple articles were included only once. Data from articles published in English were extracted from the full-texts, while data from records published in other languages were extracted from the English abstract or excluded when no English abstract was available.

\section{Results}

The PRISMA flow diagram of our literature search to review ecological risk factors associated with the circulation of the six priority viruses in northwestern Europe is given in Fig 1. Background information on each virus can be found in Additional file 1. 
Table 1 Search terms

\begin{tabular}{|c|c|}
\hline Search term & Alternatives \\
\hline West Nile virus & "West Nile virus"[Text] OR"West Nile fever"[Text] OR"WNV"[Text] \\
\hline Japanese encephalitis virus & $\begin{array}{l}\text { "Japanese encephalitis virus"[Text] OR "JEV"[Text] OR "Japanese encephalitis"[Text] OR "Japanese B } \\
\text { encephalitis"[Text] }\end{array}$ \\
\hline Tick-borne encephalitis virus & $\begin{array}{l}\text { "Tick-borne encephalitis virus"[Text] OR "FSME"[Text] OR "FSME-virus"[Text] OR "Frühsommer- } \\
\text { Meningoenzephalitis"[Text] OR "TBEV"[Text] OR "Tick-borne encephalitis"[Text] OR "TBEV-Eu"[Text] OR"TBEV- } \\
\text { Sib"[Text] OR"TBEV-FE"[Text] OR"Louping ill virus"[Text] OR"LIV"[Text] OR"OVvine Encephalomyelitis"[Text] }\end{array}$ \\
\hline Crimean Congo hemorrhagic fever & $\begin{array}{l}\text { "CCHFV"[Text] OR "Crimean Congo"[Text] OR"Crimean hemorrhagic fever"[Text] OR"Crimean haemorrhagic } \\
\text { fever"[Text] OR "Crimean Fever"[Text] OR "CCHF"[Text] OR"Hemorrhagic Fever Virus, Crimean-Congo"[Text] OR } \\
\text { "Hemorrhagic Fever Crimean"[Text] }\end{array}$ \\
\hline Rift Valley fever virus & "Rift valley fever virus"[Text] OR "RVFV"[Text] OR "Rift Valley"[Text] OR"RVF"[Text] OR"Rift Valley Fever"[Text] \\
\hline Ecological study & $\begin{array}{l}\text { "Transmission cycle"[Text] OR"ecology"[Text] OR "ecological"[Text] OR "risk factor"[Text] OR "risk model"[Text] OR } \\
\text { "ecological study"[Text] OR "ecological competence"[Text] OR"natural ecology"[Text] OR "enzootic cycle"[Text] } \\
\text { OR"epizootic cycle"[Text] OR "urban cycle"[Text] OR "Risk-modifying factor" [Text] OR"dynamics"[Text] OR"com- } \\
\text { petence" [Text] OR "Cycle" [Text] OR"environmental factor"[Text] }\end{array}$ \\
\hline Habitat & $\begin{array}{l}\text { "Forest"[Text] OR "wetlands"[Text] OR "shrubs"[Text] OR "trees"[Text] OR "bushes"[Text] OR "environment"[Text] OR } \\
\text { "urban"[Text] OR"river"[Text] OR "marshes"[Text] OR "grass"[Text] OR "grassland"[Text] OR "water reservoirs"[Text] } \\
\text { OR"natural ecology"[Text] OR "habitat"[Text] OR"green"[Text] OR"landscape"[Text], OR "habitat"[Text], OR } \\
\text { "vegetation type"[Text] }\end{array}$ \\
\hline Climate & $\begin{array}{l}\text { "Temporal"[Text] OR "temperature"[Text] OR "humidity"[Text] OR "rain"[Text] OR "precipitation"[Text] OR } \\
\text { "water"[Text] OR "weather"[Text] OR "climate" [Text] }\end{array}$ \\
\hline Geography & $\begin{array}{l}\text { "Spatial"[Text] OR "density"[Text] OR "concentration"[Text] OR "movement"[Text] OR "migration"[Text] OR } \\
\text { "abundance"[Text] OR"population and size"[Text] }\end{array}$ \\
\hline
\end{tabular}

\section{CCHFV}

Climatic factors were often invoked to explain the upsurge of CCHFV cases in recent years, as they strongly influence the survival, development, and reproduction of the principal vector, $H$. marginatum (s.l.) $[31,32]$. A dynamic population model of $H$. marginatum showed that ticks were unable to establish self-sustaining populations in areas where the yearly sum of the average daily temperature falls below 3000$4000{ }^{\circ} \mathrm{C}$, a limit roughly found at latitudes north of $47^{\circ} \mathrm{N}$ [31]. Below this temperature limit, most engorged nymphs appear in late summer and early autumn. Since the molting process is only completed after 300 cumulative degrees Celsius above the developmental zero (14-16 ${ }^{\circ} \mathrm{C}$, the minimum temperature needed for development), these nymphs are unable to molt into adults before winter and suffer higher mortalities as a result [33]. Indeed, cumulative temperatures between September and December average $800{ }^{\circ} \mathrm{C}$ in areas where $H$. marginatum has permanent populations, while the species is absent in areas where it drops below $400{ }^{\circ} \mathrm{C}$ [33]. Tick populations are also unable to persist at latitudes south of $34^{\circ} \mathrm{N}$, as engorged nymphs in these areas tend to molt in late spring and early summer, when humidity levels are too low to maintain water balance [31]. Thus, annual cumulative temperature appears to be an important barrier to further spread of $H$. marginatum, and hence CCHFV distribution [34]. However, estimates of future climate change scenarios may sharply increase suitable habitat and hence facilitate its northwards spread [35].

Hyalomma marginatum ticks become active in spring when average daily temperatures exceed $10.5{ }^{\circ} \mathrm{C}$, with optimal development between $22-27{ }^{\circ} \mathrm{C}$ and $75-100 \%$ relative humidity under laboratory conditions [36]. Tick activity lasts until early autumn [37]. In Turkey, increased tick activity in summer coincided with CCHF incidence in humans, with most cases concentrated from May through July, when mean monthly temperatures ranged between $15-20{ }^{\circ} \mathrm{C}$ [38]. In Iran, CCHF incidence peaked at mean monthly temperatures between $30-40{ }^{\circ} \mathrm{C}$ and with maximum relative humidity levels of $20-50 \%$ [39].

Various empirical and modelling studies have demonstrated that CCHFV risk areas are associated with a range of climatic factors permissive for establishment of $H$. marginatum populations [21, 32, 38-42], although others did not [43]. CCHF incidence in humans was positively related to mean monthly temperature in Turkey, Iran and Bulgaria [38, 39, 41, 42] and maximum relative humidity $(\mathrm{RH})$ in Iran [39]. These correlations are likely to arise through the indirect impact of climate on tick life-cycle dynamics and survival. Higher temperatures and humidity facilitate higher tick development rates, transstadial virus transmission, increased tick questing activity, and higher host parasite loads, all of which promote virus circulation [32, 39].

Relationships between CCHFV and precipitation are more complex. Rainfall was positively associated with 


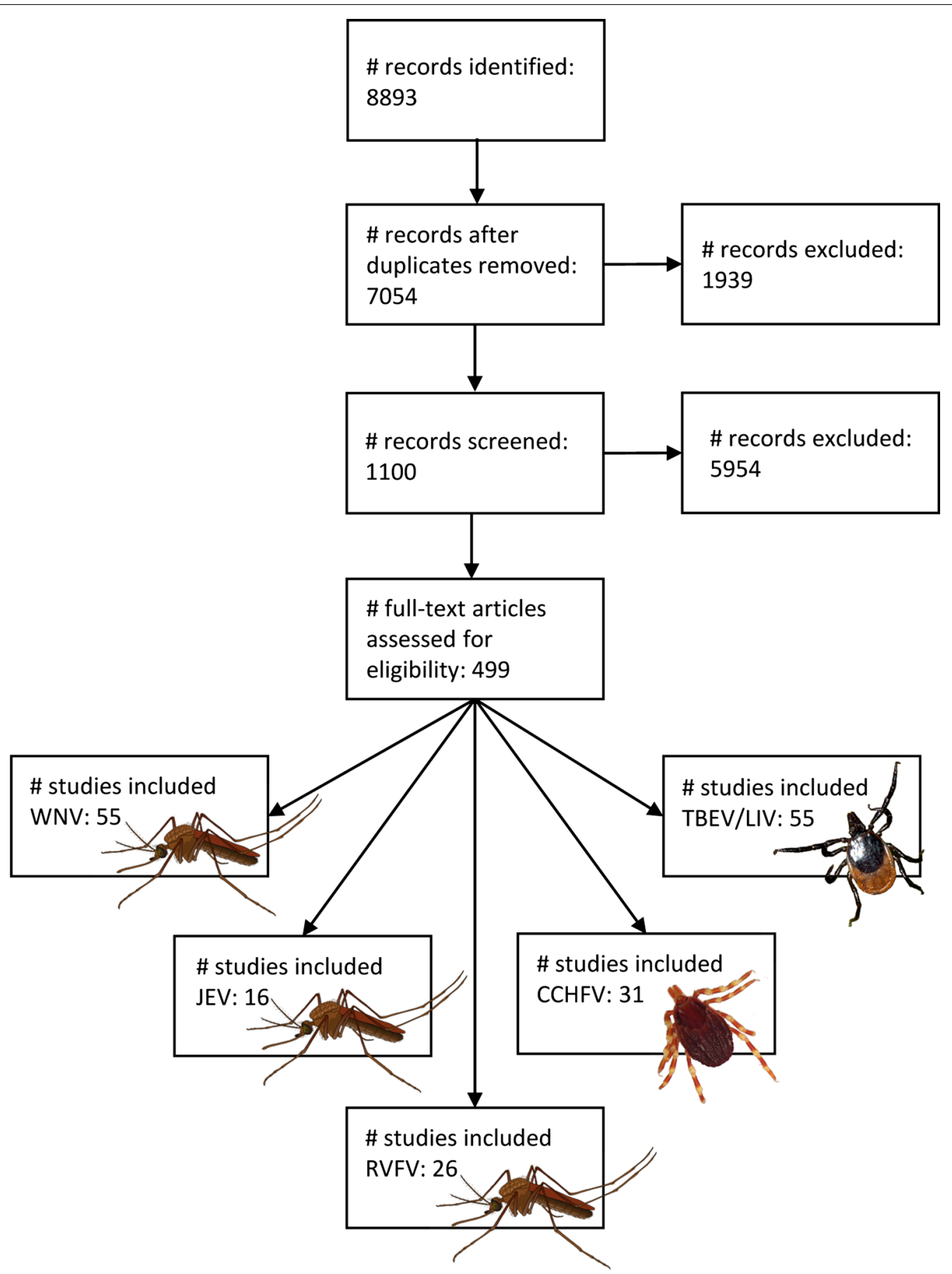

Fig. 1 PRISMA flow diagram of the literature search

monthly CCHF incidence in Turkey, with mean monthly rainfall varying between $30-70 \mathrm{~mm}$ [38]. In contrast, in Senegal rainfall was negatively associated with CCHFV seropositivity in both humans and sheep, with IgG antibody prevalence dropping from $31 \%$ to $0 \%$ when annual precipitation increased from $450 \mathrm{~mm}$ to over $1000 \mathrm{~mm}$
[44]. In Iran, monthly accumulated rainfall (maximally $150 \mathrm{~mm}$ for each of the four seasons) was inversely correlated with CCHF incidence at a lag of one month, but positively correlated at a lag of five months [39]. These studies show that the relationship between CCHFV circulation and precipitation remains contentious and may 
depend on the climate zone, which in the given examples varied from Mediterranean, to tropical and arid regions, respectively.

Elevation was also related to CCHFV risk, with increased seropositivity in people living at altitudes of $>400 \mathrm{~m}$ [45] or $>600 \mathrm{~m}$ [46]. Dogan et al. [47] also found a strong, positive relationship between CCHF incidence and elevation, but only until an elevation of $1340 \mathrm{~m}$, suggesting an altitude threshold for Hyalomma spp. ticks. Aker et al. [38] found the highest incidence of CCHF in humans at elevations between 1000-1200 m. However, as altitude is correlated with factors such as temperature, precipitation, vegetation, and host densities, the effect of altitude cannot be separated from the aforementioned factors so that the underlying causal mechanisms remain unclear.

Besides climatic conditions, a range of other environmental factors may contribute to higher levels of CCHFV circulation by increasing tick habitat suitability or seasonal activity. These factors are often related to particular land cover categories. For example, human cases of $\mathrm{CCHF}$ were positively related to the proportion of areas covered by shrub, grassland, and herbaceous vegetation $[42,48]$, the Normalized Difference Vegetation Index (NDVI) [42, 49], and high rates of habitat fragmentation in agricultural areas $[21,42,43]$. This corresponds to the preferred habitat of Hyalomma ticks: savanna and lightly wooded foothill biotopes [42, 50]. Intermingling of fragmented farmland with forested areas not only provides suitable habitat for ticks but may also stimulate movement of larger animals that carry adult ticks to new locations $[21,42,51]$.

Increased densities of wild and domestic ungulates and (illegal) livestock trading were also found to be key factors for CCHFV spread throughout the western Palaearctic region [32, 38, 39], although livestock density was not always correlated with CCHF incidence in humans [42]. Human population density has not been shown to correlate with CCHF incidence, but activities that increase human interaction with potentially infectious animals did, such as hunting practices and animal husbandry $[21,41,42,45]$. In fact, the major human risk groups for CCHFV are people who come into close contact with livestock, such as farmers and abattoir employees [39]. Environmental and social changes that increase the risk of CCHFV in humans may have varying causes, including war conflicts (e.g. past outbreaks of CCHFV occurred in Crimea during WWII and in Kosovo in 1999), changes in animal husbandry practices, agricultural reforms, and abandonment of arable land [17, 43, 52].

Finally, several Hyalomma species, including H. marginatum, have a two-host life-cycle in which ticks remain on their host while molting from larva to nymph [53].
These ticks may therefore be attached to their first host for several weeks, in contrast to three-host ticks which drop off after each blood meal, usually within a few days [54]. The two-host life-cycle of $H$. marginatum in combination with transovarial transmission of CCHFV favors long-distance dispersal of both vector and virus via migratory birds or livestock trade $[31,39,55]$. Although no evidence exists that wild birds become viremic, immature ticks are frequently introduced into northern latitudes by passerine birds during spring migration [56-58]. Adult $H$. marginatum ticks have also been found on a horse in the Netherlands [59] and on the clothing of a person in Germany [60], and these ticks may have initially arrived as a nymph and molted to the adult stage after arrival in the country via migratory birds [61].

\section{TBEV}

Several studies have demonstrated that a high prevalence of co-feeding between uninfected larvae and infected nymphs of Ixodes ricinus ticks on rodent hosts is the most critical factor in TBEV transmission [62-69]. Interstadial co-feeding only occurs when the seasonal activity of nymphs and larvae coincides, for which a specific combination of climatic and host factors is required [62, 63]. Specifically, warm summers allow for rapid development of eggs, but rapidly decreasing temperatures in autumn sends the emergent larvae into behavioral diapause during winter. Subsequent rapidly rising temperatures and humidity in spring causes larvae to become active at the same time as nymphs, allowing for efficient virus transmission via co-feeding [62-64, 69]. Experimental studies have indeed shown that the ratio of larvae to nymphs on rodent hosts increase with $\mathrm{RH}$ [70], and that $\mathrm{RH}$ also positively affects TBEV infection rate and transstadial transmission in ticks [71]. In Norway, TBEV prevalence in ticks was highest in sites with the highest mean $\mathrm{RH}$ and lowest mean saturation deficit (SD) [72]. In the Czech Republic, TBE incidence in humans was positively correlated with daily mean, maximum and minimum temperature as well as soil temperature at a depth of $5 \mathrm{~cm}$, probably mediated by the direct effect of climatic factors on the abundance and/or questing behavior of $I$. ricinus [73]. Indeed, microclimatic factors play a crucial role in the life-cycle of $I$. ricinus, with tick abundance being positively correlated with temperature and RH but negatively with SD $[69,74-78]$. Conversely, the negative impact of altitude on tick abundance and TBE incidence is probably confounded by climatic factors, as lower temperatures at higher altitudes deplete a tick's fat and water reserves, shorten tick questing period and development rates, and delay embryogenesis [79].

Climate change has often been implicated in the rise of TBEV [80-83], but the subject remains controversial 
[84-87]. Lindgren \& Gustafson [88] showed that in Sweden, incidence of TBE in humans increased under a combination of (i) two consecutive mild winters; (ii) daily minimum temperatures favoring spring development $\left(8-10{ }^{\circ} \mathrm{C}\right)$ and extended autumn activity $\left(5-8{ }^{\circ} \mathrm{C}\right)$ in the preceding year; and (iii) spring temperatures that allow tick activity $\left(5-8{ }^{\circ} \mathrm{C}\right)$ in the incidence year. Thus, the increase in TBE incidence in humans in Sweden since the 1980s may be related to a combination of milder winters and early arrival of spring, which are favorable conditions for the tick vector as well as host and reservoir animals [88]. However, Randolph [89] argued that there was no warming during the 1984 TBEV outbreak in Sweden. While increased temperatures did precede the dramatic increase of TBE cases in central and eastern European countries in 1993 [90, 91], the spatial-temporal heterogeneity of the TBEV upsurge could not be explained by climate change alone $[86,92]$. Instead, a combination of biotic, abiotic and human factors has been identified, many of which related to the fall of the Soviet Union and subsequent socio-economic transition [92, 93]. The most significant of these variables was human behavior, both recreational and subsistence, that caused higher exposure to infected ticks [86, 93]. For example, tick bites increased when dry weekends were followed by wet weeks, irrespective of local tick abundance, suggesting that TBEV risk could be better explained by humans harvesting mushrooms, berries and other forest products than by climate per se [89].

Apart from shifts in climatic variables and human behavior, both empirical and modelling studies have shown the important role of large wildlife, particularly deer, in TBEV epidemiology [66, 68, 94-99]. Although deer are not competent for TBEV transmission [62], they are among the most important host species for adult $I$. ricinus ticks [100]. As a consequence, deer are able to greatly amplify tick abundances, but at the same time divert tick bites from small rodents, which are competent hosts [95]. These two competing effects result in a humpshaped relationship of deer density with the number of ticks feeding on rodents, and hence also with the basic reproduction number $R_{0}$ (the average number of secondary infections produced by an infected individual in a fully susceptible host population [101]) for TBEV [96, 98]. Thus, deer initially have a positive (amplification) effect on the number of co-feeding ticks and TBEV persistence until a certain threshold density is reached, after which tick bites are 'wasted' as the ratio of blood meals on competent versus incompetent hosts decreases, triggering a decline (dilution) of TBEV prevalence in ticks $[68,98]$. In addition, deer are able to transport infected ticks into previously naive populations [102, 103], as do (migratory) birds [104].
Well-connected broad-leaf and mixed forest patches with open areas were also positively correlated with the presence of TBEV, as they provide suitable habitat for roe deer, rodents and ticks $[105,106]$. Although I. ricinus ticks are found in a wide range of habitats, they are most strongly associated with woodlands and forests with thick undergrowth, which offer favourable microclimatic conditions [107, 108]. Likewise, Apodemus flavicollis, the rodent most often incriminated in non-viremic TBEV transmission, is generally considered a species of mature forests with abundant undergrowth [97]. Changes in land management and forest structure that improve habitat suitability of forest rodents, as well as changes in hunting practices that affect roe deer densities are likely to play a major role in TBE upsurges, particularly in western Europe [97].

The contribution of each of these factors to local virus circulation may vary between regions. For example, a study from the Czech Republic argued that there were no socio-economic shifts, land-use changes, or changes in the abundance of game species that could explain the recent TBEV upsurge [82]. The authors suggested that human recreational activity (i.e. mushroom picking) and a warming climate were the most important drivers of the increase in TBE incidence [82, 109]. Further, a study from Sweden found a positive relationship between human cases of TBE and the number of red foxes Vulpes vulpes [110]. The authors suggested that red foxes may play a role in TBEV epidemiology by potentially acting (i) as reservoir hosts; (ii) as carriers and disseminators of ticks; (iii) as predators that directly suppress the abundance of incompetent hosts; and/or (iv) as mesopredators that indirectly facilitate competent hosts by suppressing the abundance of small carnivores, which prey upon small rodents [110]. Hence, the relative role of the most important factors-climate change, human behavior, relative abundance of competent $v s$ incompetent hosts-in determining TBEV circulation varies spatially.

\section{LIV}

Very few empirical studies have considered the environmental (both biotic and abiotic) risk factors associated with LIV circulation in endemic areas [79, 111, 112]. However, given that LIV is closely related to TBEV and is transmitted by the same tick vector (I. ricinus), many of the factors affecting TBEV circulation may also be involved in LIV transmission dynamics. For example, the distribution of LIV across the British Isles is tightly linked to those areas where its vector is most abundant, i.e. upland grazing areas [113]. Here, I. ricinus ticks become active when average daily spring temperature reaches $7{ }^{\circ} \mathrm{C}$ [113]. The abundance of larvae and nymphs on the British Isles was also found to be positively associated 
with deer densities [79]. In addition, nymph and adult tick abundances were strongly negatively associated with altitude after correcting for biotic factors such as hosts and vegetation, a relationship most likely explained by decreasing temperatures and humidity with increasing elevation [79]. Larval and nymphal I. ricinus both exhibit a similar seasonal pattern in abundance in parts of the LIV distribution, allowing for interstadial co-feeding transmission via mountain hares Lepus timidus, an essential element in LIV maintenance [62, 114].

Laurenson et al. [112] demonstrated the critical role of mountain hare in the LIV transmission cycle with a field experiment in the Scottish Highlands. Mountain hares were shown to be important amplifying hosts for ticks of all stages, and could maintain tick populations under low mountain hare densities and when large host species (e.g. deer, sheep) were either absent or treated with acaricides. Further, a reduction in mountain hare populations not only dramatically reduced tick loads but also LIV prevalence in red grouse Lagopus lagopus scoticus [112]. These results are in concordance with modelling studies of LIV transmission dynamics, which have shown that the virus could be maintained in the absence of red grouse through non-viremic transmission in mountain hares via cofeeding ticks $[115,116]$. In contrast, the virus could not persist when red grouse density fell below $30 \mathrm{~km}^{-2}$ and mountain hares were absent [115]. Red grouse rarely feed adult ticks, so that LIV was only able to persist in conjunction with other species that function as reproduction hosts, such as red deer or mountain hares [112].

More recent modelling studies have shown the importance of incorporating spatial variation in host abundance and movement for predicting virus persistence and vector abundance [117]. Specifically, Watts et al. [117] showed that allowing a small proportion of the red deer Cervus elaphus population to move between sites with and without mountain hares allowed persistence of LIV at the hare-free site, even at very low deer densities. This may also explain why LIV prevalence in red grouse is not always reduced in sites where hare density is reduced [117]. In addition to movement of wildlife, movement of livestock has also been implicated in the spread of LIV. Phylogenetic analyses revealed that trade in cattle and sheep may account for the spread of LIV across the British Isles and its introduction into Norway [118].

\section{JEV}

Temperature, humidity and precipitation stimulate the growth, survival and dispersal of JEV mosquito vectors as well as virus propagation $[119,120]$. In China, incidence of JE in humans has a strong seasonal pattern, with cases rapidly increasing from June onwards, peaking in August and decreasing again from September onwards [120, 121]. Several empirical studies have shown this trend to be positively associated with monthly mean RH $[122,123]$, monthly mean temperature with lag times ranging from zero to three months [120-124], and yearly minimum and mean temperatures [125]. Epidemic peaks in China were also positively related to annual mean temperature (AMT), with only few cases when AMT was below $20{ }^{\circ} \mathrm{C}$, potential epidemics when AMT was between $25-30^{\circ} \mathrm{C}$, and epidemic peaks when AMT was above $30{ }^{\circ} \mathrm{C}$ [120]. One study found lower threshold values of $25{ }^{\circ} \mathrm{C}$ and $21{ }^{\circ} \mathrm{C}$ for maximum and minimum temperature respectively, above which monthly JE incidence increased with temperature [122]. Temperature was also positively correlated with mosquito densities in JEV endemic areas in India, were optimal temperatures for JEV vectors ranged between $22.8-34.5{ }^{\circ} \mathrm{C}[126,127]$. Higher temperatures increase development and winter survival rates of mosquito larvae, while shortening the incubation period for virus replication within mosquitoes as well as time between blood meals. This reduces the transmission time from mosquito vector to animal and human hosts [128]. Thus, higher temperatures allow mosquito populations to increase more rapidly and to reach large, stable population sizes for longer, thereby facilitating JEV transmission [122, 129].

Relationships between JEV circulation and precipitation were more complex. While transmission of JEV occurs year-round in the tropics, seasonal epidemics typically start shortly after the onset of the rainy season when mosquito densities peak [129]. While several studies reported positive correlations between human cases and precipitation [120,122, 124, 127], others found a negative relationship with lag times ranging from 0 to 4 months [121, 130], or a unimodal pattern with highest incidences at intermediate rainfall [125]. Chen et al. [131] found the effect of precipitation on JEV risk to be positive only up to a threshold value of $350 \mathrm{~mm} /$ day, above which mosquito breeding habitats were probably destroyed. However, these torrential rainstorms of $>350 \mathrm{~mm} /$ day are absent in temperate areas. This may also explain the negative relationship of rainfall with JE incidence in the study of Bai et al. [121] carried out in an area with a monsoon climate where annual precipitation exceeded 1000-1400 mm. An ecological niche modelling (ENM) study for Cx. tritaeniorhynchus in Asia, based on mosquito presence records and environmental variables, indicated that mean precipitation of the wettest quarters $(797 \mathrm{~mm})$ and elevation $(153 \mathrm{~m})$ were the most important contributors to the vector distribution model, with mosquitoes rarely occurring in areas above $1000 \mathrm{~m}$ [128]. An ENM study from China also reported a negative correlation between elevation and the presence of JE, possibly 
due to reduced temperatures and/or lower populations of humans, livestock, and ardeid birds [125].

Apart from climatic conditions, human incidence of JEV was positively related to pig density, the level of viremia in pigs, human proximity to pig farms, human population density, and the virulence of the virus [120, $124,125,128,132,133]$. The principal mechanisms that allow JEV introduction and subsequent establishment in new areas include bird migration, movement and transportation of infected hosts (particularly pigs), the spread of mosquitoes by wind or trade (e.g. via ship deck cargo or aircraft), and changing land-use and agricultural practices following deforestation [129, 134-136]. Low lying, flooded areas such as rice paddies are the primary larval habitat for $C x$. tritaeniorhynchus mosquitoes. The creation of new rice paddies or physical and chemical alterations to these breeding sites may have a strong influence on vector abundance and hence influence the establishment and/or spread of JEV [134]. In particular, paddy height, dissolved oxygen, and ammonia nitrogen have been shown to negatively impact larval abundances, whereas water temperature and nitrate nitrogen had consistent positive effects, both within and between seasons [16]. The expansion of rice growing areas over the past decades has increased adult mosquito population densities and may have subsequently contributed to human exposure to JEV [128].

\section{WNV}

WNV ecology is controlled by a wide range of local mosquito, host reservoir and virus intrinsic factors, including vector competence, host preferences and longevity of mosquito vectors, morbidity, mortality and reservoir competence of vertebrate host species, and WNV strain virulence [55, 137-147]. The presence or absence of $\mathrm{WNV}$ in an area is determined by a complexity of interacting ecological factors, such as temperature, precipitation, and the simultaneous presence of sufficient densities of susceptible hosts and competent vectors $[139,140,148,149]$. However, the direction and strength of correlations with these factors are not always consistent [149]. For example, laboratory studies have shown that WNV infection and transmission rates increase with temperature in some mosquito biotypes but not in others [139], and that some virus strains are transmitted more efficiently with increasing temperature than others [150]. Likewise, the effect of precipitation on WNV epidemiology differs between regions and may depend on vector species and lineage, as well as virus strain [149].

In the Danube Delta in Romania, warmer spring temperatures were positively correlated with mosquito densities and increased WNV infection rates in mosquitoes with a lag of 20 days from the onset of temperature rise.
In contrast, precipitation was negatively correlated with mosquito infection rates with a lag of 30 days, whereas there was no correlation with mosquito densities [151]. While higher precipitation is generally believed to augment mosquito densities by increasing the availability of suitable breeding habitat, the opposite may be true for wetland ecosystems such as the Danube Delta [152]. Here, drought reduces water flow, thereby creating stagnant water pools with higher concentrations of organic matter, which are ideal conditions for mosquito breeding $[149,151,153]$. In addition, birds concentrating around small water holes during droughts can increase birdmosquito interactions [149, 153]. A number of other studies have also found a link between increased WNV transmission and reduced precipitation [154-158] and increased temperatures during summer months [149]. In their study across the European continent, Marcantonio et al. [153] showed that WNV incidence was indeed positively correlated with high temperatures and drought during summer, but also with high precipitation in late winter/early spring.

In addition to climatic factors, variation in land use, host community, urbanization, and human behavior have been implicated as factors influencing WNV outbreaks [149, 153, 159-161]. For example, the percentage of irrigated crop lands and highly fragmented forests were positively related to WNV incidence across Europe [153]. Irrigated crop lands provide suitable breeding habitat for mosquito vectors, whereas forest fragmentation may increase contact rates between mosquitoes, reservoir hosts and humans [153]. A study from the Camargue wetlands, France, identified dry bushes, open water and woodlands as the major risk areas associated with WNV cases in horses, possibly by providing nesting and resting areas for birds [162]. Further, rice fields and reeds, which are ideal habitat for Culex spp. larvae, covered a large area within a $1 \mathrm{~km}$ buffer zone around localities from which WNV cases were reported [162]. In a follow-up study, Pradier et al. [163] showed a positive correlation between WNV circulation in southern France and one landscape metric (i.e. the interspersion and juxtaposition index, IJI) and one land cover class (i.e. heterogeneous agricultural areas). Both variables represent landscapes with spatial configurations that may facilitate interactions between competent vectors and reservoir hosts.

Many of the ecological processes that drive WNV outbreaks in the Old World differ from those of the New World [153], and seemingly inconsistent findings characterize both systems. As in Europe, relationships between WNV occurrence and specific intrinsic or extrinsic factors of vector, virus and host varied across the geographical range of WNV in the USA. For example, the correlation between human incidence of WNV and 
precipitation of the preceding year was found to be positive in the eastern USA, but negative in the west [157]. The authors hypothesized that differences in the ecology of mosquito vectors may be responsible for this difference, although rainfall patterns also differ between the east and west. Likewise, WNV incidence in the northeastern USA was positively associated with urban land cover [164], while in the western USA it was positively associated with agricultural land cover, a discrepancy that was explained by the geographical distribution of different WNV vectors [165]. Some Culex species tend to be well-adapted to anthropogenic environments, and urbanization may increase the number of water bodies that allow for mosquito oviposition, hence increasing vector abundances [159]. Indeed, Brown et al. [166] showed that within urban areas, the abundance of four important WNV vector species was positively correlated with proximity to water, NDVI, and Disease Water Stress Index (DWSI), which is a measure of the internal water content of vegetation. Further, warmer urban microclimates increased mosquito biting and development rates, increased the survival of overwintering virus-infected mosquitoes, and facilitated virus replication within mosquito vectors as well as transmission to susceptible hosts $[23,153,160,167,168]$.

In contrast to Europe, several studies from the USA have suggested a potential role for avian diversity in reducing WNV transmission [159, 169-171], in line with predictions derived from the "dilution effect" hypothesis [172]. According to this hypothesis, high avian diversity reduces WNV transmission by redistributing vector blood meals across a much wider range of bird species, many of whom are poor reservoir hosts for WNV [169]. Negative correlations with avian diversity have been reported for WNV prevalence in mosquito vectors [169, 170], density of infected mosquitoes [170], and WNV incidence [169-171]. In contrast, Loss et al. [173] did not find support for a negative correlation of avian diversity with WNV seroprevalence in birds nor with mosquito infection rate. Moreover, the possibility of a dilution effect in WNV transmission has received considerable criticism, and these authors have argued that other intrinsic and extrinsic factors, such as heterogeneity in mosquito host preference, host reservoir competence, temperature, and precipitation, may be more important than avian species richness in driving local WNV transmission [173-175].

A striking difference between the USA and Europe, regarding the role of birds in WNV epidemiology, is the mass mortality of birds in the USA and lack thereof in Europe. Although WNV-neutralizing antibodies have been found in a wide range of wild bird species in Europe, their prevalence is usually rather low, and it remains unclear which species act as reservoir hosts [176-181]. Recent studies confirmed however that European carrion crows (Corvus corone) and Eurasian jackdaws (Corvus monedula) are as susceptible to WNV as American corvids [146, 182, 183]. This suggests that these birds, as well as closely related species such as the hooded crow (Corvus cornix) could also act as amplifying hosts in Europe $[178,183]$. Other studies found high levels $(11-70 \%)$ of antibodies in rock pigeons (Columba livia), suggesting that this species could facilitate the spread of WNV in Europe [23, 184]. Rock pigeons are abundant, fly long distances regardless of seasonal migrations, and, being an important prey of predatory birds, can contribute to oral transmission of WNV through the food chain [23]. A recent experimental study demonstrated that this species is indeed a competent reservoir host for WNV in Europe [185]. Figuerola et al. [178] found that body size of birds was a significant predictor for antibody prevalence. Larger hosts may be more readily infected with WNV due to their larger surface area and higher $\mathrm{CO}_{2}$ production, which may attract a larger number of mosquitoes.

While infected mosquitoes may spread WNV over long distances, either via unassisted means (e.g. by wind currents) or assisted means (e.g. via boats or aircraft) [186], the principal route for WNV dissemination is via infected migratory birds, which carry WNV to novel areas as far north as Sweden [179, 187]. In southern Spain, trans-Saharan migratory birds had both higher antibody prevalence and titers than short-distance migrants and resident bird species [180]. Although this does not provide definite proof that these specific bird species are involved in WNV-transmission, it does suggest that long-distance migrants spend part of their lives in African regions with greater circulation of WNV [6, $147,176,177,188,189]$. Once introduced in favorable habitat, WNV may overwinter in infected female mosquitoes as well as in resident birds, removing the need for continuous re-introductions by migratory species [176, 190].

\section{RVFV}

Historical outbreaks of RVFV since the 1950s in East Africa were closely linked to climate anomalies [191196]. Epidemics and epizootics typically occur after periods of heavy rainfall and flooding, which create temporary mosquito breeding pools ("dambos") that allow for the development of large numbers of mosquitoes [193, 197-201]. Periods of exceptional rainfall in East Africa are associated with the warm phase of the El Niño/Southern Oscillation phenomenon (ENSO) [202]. Analysis of past outbreaks have shown that over three quarters of RVFV events have occurred during warm ENSO periods [194, 203]. Another indicator of increased 
precipitation is greener vegetation, which can be detected by the satellite derived NDVI. Spatiotemporal analysis of NDVI, rainfall, and several indicators of ENSO have all been successfully used to predict RVFV outbreaks [194, 196, 204-206]. Yet some past outbreaks in other parts of Africa were not associated with increased rainfall or even occurred during droughts [207, 208]. Human activities such as irrigation and dam construction were suggested to have contributed to these events by providing suitable larval habitat [182].

In their study from Kenya, Hightower et al. [209] showed that while rainfall and derived measures such as NDVI are important indicators of RVF incidence in humans, there are in fact a number of geological, geographical and meteorological factors that together create the optimal conditions for RVFV occurrence. Specifically, RVF incidence was higher in (i) arid regions $(<700 \mathrm{~mm}$ annual rainfall) that had received more rainfall than other parts of the country prior to an RVFV outbreak; (ii) areas characterized by lower elevations $(<500 \mathrm{~m})$, due to the limited abundance of vectors at higher elevations; (iii) flat landscapes with depressions that transform into water pools following heavy rainfall, thereby providing larval habitat; (iv) areas with soil textures that retain water easily, facilitating rehydration of mosquito eggs; and (v) areas with dense bush vegetation that provides mosquitoes with landing zones and resting areas [209].

Other recent studies also showed that RVFV occurrence was positively associated with vegetation cover $[210,211]$, the water holding capacity of soil (clay and loam were significant risk factors; $[212,213]$ and increased rainfall ( $>405 \mathrm{~mm}$ during the previous 2 months; [213]). Likewise, Glancey et al. [205] argued that while rainfall and NDVI are indicative of epizootic RVFV outbreaks in South Africa, other ecological factors probably play a role as well, including close proximity to water bodies and surrounding land use, particularly shrubland, grassland, or agricultural areas. In Madagascar, recurrent transmission of RVFV was associated with a wet, temperate climate, high altitude, paddy fields and vicinity to a dense forest [214]. Thus, a range of environmental factors that provide suitable mosquito habitat at each life stage contribute to RVFV emergence [209].

As for all mosquito-borne viruses, temperature also plays an important role in the ecology of RVFV [201, 210, 211]. Higher temperatures $\left(17-35{ }^{\circ} \mathrm{C}\right)$ allow mosquito populations to increase more rapidly, reaching large, stable population sizes for longer periods of time [122, 129], and facilitates viral replication and transmission in both Aedes spp. [215] and Culex spp. [216] mosquitoes.

Finally, the emergence and spread of RVFV across Africa and beyond is also linked to economic activities, in particular trade and movement of ruminant livestock and goods [25, 197, 217]. For example, phylogenetic analyses of virus isolated from Yemen and Saudi Arabia revealed that the emergence of RVFV in the Arabian Peninsula after 2000 was probably caused by the introduction of infected livestock from the African continent [206, 218, 219]. In Tanzania, Sudan, and Madagascar, animal movement into other ecological zones, where large populations of competent Culex mosquito species were already present, amplified outbreaks by creating secondary foci of RVFV [196, 214, 220]. Trade in goods also poses a risk, as it may aid the introduction of infected Aedes mosquito eggs, whereas infected adults may be transported by aircraft or cargo $[217,221]$. Thus, both environmental and social factors are important to consider when assessing the risk of emergence of RVFV [206].

\section{Discussion}

We systematically reviewed 183 studies on the ecological risk factors associated with the circulation of six priority arboviruses (JEV, WNV, RVFV, CCHFV, TBEV and LIV) that are of considerable concern to northwestern Europe (Fig. 1). Climate, habitat, animal density and movement were most often correlated with increased disease risk, with each of these factors contributing to virus circulation either directly or indirectly via their impacts on the virus, its vectors and/or hosts (see Additional file 2: Table S1). These factors can therefore be used for riskbased surveillance programs, although the strength and direction of their relationship with disease risk sometimes differs between viruses and may depend on local conditions.

Climatic factors were identified as important drivers for arbovirus outbreaks and sustained arbovirus circulation through a direct effect on vector capacity and, in the case of TBEV, on the occurrence of interstadial co-feeding. However, the relationships between climatic conditions and arbovirus outbreaks were not always consistent due to spatial and temporal differences in local biotic and abiotic factors [153, 222]. For example, both negative and positive relationships with precipitation were found for RVFV, JEV and CCHFV. Laboratory experiments can help elucidate the underlying mechanisms and explain correlations observed in the field. Such experiments have shown that vector competence increases with temperature in some mosquito biotypes but not in others [139], and that some virus strains are better adapted to warmer climates than others [150]. Similar optimum conditions exist for precipitation. Rising temperatures as predicted under current climate change scenarios have often been hypothesized to change current patterns of disease incidence and distribution [222, 223]. In Europe, many vectors and pathogens are expected to expand both northwards and to higher latitudes, e.g. I. ricinus, 
H. marginatum, WNV [35, 224, 225], while exotic arboviruses like RVFV may become established [226, 227]. However, the potential role of climate change in the distribution and incidence of some arboviruses like TBEV remains disputed [84-87] or poorly investigated like JEV [228]. It is likely that while some areas in Europe become more favorable for some of these vectors and/ or pathogens, others become less favorable with rising temperatures.

Specific types of vegetation or land use were often found to be associated with increased disease risk through their impacts on suitable habitat for vectors and (reservoir) hosts, thereby increasing vector capacity. Agricultural practices such as the creation of rice paddies, abandonment of farmlands, and a high rate of habitat fragmentation may provide ideal breeding sites for vectors, increase host and vector densities and contact rates, and stimulate host and vector movement between habitat patches [17, 43].

Animal density and movement contributes to viral spread, threatening areas where competent vectors are already present or being co-introduced. Wetlands or other habitats where migratory birds concentrate in large flocks therefore pose a relatively larger risk for the introduction of CCHFV-infected ticks and/or that of birdassociated arboviruses such as WNV or JEV [56, 134, 229]. Livestock trading has been implicated in the spread of RVFV [25], CCHFV [230] and LIV [118] throughout the western Palaearctic region. Some mosquito species can maintain WNV, JEV and RVFV via vertical transmission (adults to eggs) [129, 231], so that trade of goods, like used car tires and ornamental plants harboring mosquito eggs and/or larvae can favor long-distance dispersal of both virus and mosquito species to novel areas [232234]. Virus introduction and local transmission through travel of viremic people to non-endemic areas has been documented for various arboviruses as recently illustrated again for chikungunya virus in France and Italy [5, 235]. However, as humans are dead-end hosts for the arboviruses in this review, human travel is unlikely to play a role in the spread of these arboviruses.

Studies on drivers of arbovirus outbreaks typically correlate ecological variables to disease incidence rates in humans and/or animals, so that the underlying causal mechanisms remain unclear in many of these studies. For example, climate may not be the single most important factor driving the recent temporal patterns in the epidemiology of some vector-borne diseases, as human activities that increases risk of exposure (e.g. harvesting of forest products) are often strongly confounded with climatic variables $[86,89]$. Therefore, the perceived relationships between climate and clinical cases may be better explained by human behavior than with vector or virus ecology [73]. Socio-economic changes that increase human activities in risky forest habitats (e.g. hunting practices, animal husbandry, collecting mushrooms) can increase exposure regardless of the abundance of infected vectors [86]. This stresses the need of directly studying the impact of environmental conditions on vectors and arboviruses, both in the field and through laboratory experiments $[139,151]$ while studying the influence of human behavior on risk of exposure.

Nevertheless, certain sets of ecological conditions that may facilitate the introduction and subsequent establishment of the six arboviruses discussed here can be used to target surveillance in areas where these viruses have yet to establish. These include abiotic conditions, habitat characteristics, and abundances of competent vectors and (reservoir) hosts (Additional file 2: Table S1). Specifically, local abundances of migratory birds returning from Africa and/or the Mediterranean can be used to identify areas where WNV or CCHFV-infected Hyalomma ticks may be introduced [56, 236], whereas data on pointto-point international trade of livestock originating from endemic areas is relevant for identifying locations of potential introduction of RVFV, LIV, and CCHFVinfected ticks [25, 237]. For arbovirus establishment, data on local densities of competent reservoir hosts (e.g. ruminant livestock for RVFV and CCHFV, ardeid birds and pigs for JEV, wetland birds and corvids for WNV, sheep for LIV) and arthropod vectors (e.g. Culex and Aedes mosquitoes, I. ricinus and Hyalomma ticks), as well as particular vegetation types (e.g. habitat fragmentation and shrubland for CCHFV, broad-leaf and mixed forests for TBEV, water bodies for JEV, WNV and RVFV) are relevant for targeting surveillance. Finally, differences in local abiotic conditions between endemic areas and areas of potential emergence, such as temperature, humidity, and precipitation, are important to consider when selecting surveillance sites.

\section{Conclusions}

Our review reflects the complex ecology of vector-borne diseases, with the establishment of sustained transmission and the emergence of human and/or animal disease influenced by multiple factors. Zoonotic vector-borne diseases may be present well before human illness is observed in routine (syndrome-based) surveillance programs and are therefore amenable to early warning surveillance, which could lead to timely risk management. There is an urgent need for both cost-effective and efficient surveillance programmes that focus sampling in the right place at the right time, ideally targeting multiple arboviruses and vectors simultaneously. Implementing such surveillance programmes requires extensive knowledge on the ecological factors driving increased densities 
of infected vectors. The current review therefore provides baseline information on suitable ecological conditions under which outbreaks of six priority arboviruses can occur. The many common denominators between the arboviruses discussed here should facilitate a focused surveillance effort, targeting multiple arboviruses in specific high-risk areas. However, existing differences in the specific climatic conditions, habitat type, and host species that are important for each specific arbovirus, will determine the extent to which high-risk areas of different arboviruses overlap and hence whether the targeting of multiple arboviruses simultaneously is feasible in an adequate manner enabling sensitive early-warning.

\section{Additional files}

Additional file 1. Background on each virus.

Additional file 2: Table S1. Ecological risk factors for each virus.

\section{Abbreviations}

WNV: West Nile virus; JEV: Japanese encephalitis virus; RVFV: Rift Valley fever virus; TBEV: tick-borne encephalitis virus; LIV: louping-ill virus; CCHFV: CrimeanCongo hemorrhagic fever virus; PRISMA: Preferred Reporting Items for Systematic Reviews and Meta-Analyses; RH: relative humidity; NDVI: Normalized Difference Vegetation Index; SD: saturation deficit; $\mathrm{R}_{0}$ : basic reproduction number; AMT: annual mean temperature; ENM: ecological niche modelling; DWSI: Disease Water Stress Index; ENSO: El Niño/Southern Oscillation phenomenon.

\section{Acknowledgements}

Not applicable.

\section{Authors' contributions}

CBEMR, MPGK, and WFB conceived the study. NBC and RM performed the systematic literature search. HJE, CBEMR, and WFB wrote the manuscript. CBEMR and WFB jointly supervised the project. All authors read and approved the final manuscript.

\section{Funding}

This study was financially support by a ZonMw grant (522001004).

\section{Availability of data and materials}

All data generated or analyzed during this study are included in this published article and its additional files.

\section{Ethics approval and consent to participate}

Not applicable.

\section{Consent for publication}

Not applicable.

\section{Competing interests}

The authors declare that they have no competing interests.

\section{Author details}

${ }^{1}$ Resource Ecology Group, Wageningen University \& Research, Wageningen, The Netherlands. ${ }^{2}$ Present Address: Laboratory of Entomology, Wageningen University \& Research, Wageningen, The Netherlands. ${ }^{3}$ Department of Viroscience, WHO CC for arbovirus and viral hemorrhagic fever reference and research, Erasmus University Medical Centre, Rotterdam, The Netherlands. ${ }^{4}$ Centre for Infectious Disease Control, National Institute for Public Health and Environment (RIVM), Bilthoven, The Netherlands. ${ }^{5}$ Vogeltrekstation-Dutch Centre for Avian Migration and Demography, Netherlands Institute of Ecology
(NIOO-KNAW), Wageningen, The Netherlands. ${ }^{6}$ Centre for Monitoring of Vectors (CMV), National Reference Centre (NRC), Netherlands Food and Consumer Product Safety Authority (NVWA), Ministry of Economic Affairs, Wageningen, The Netherlands.

Received: 27 November 2018 Accepted: 19 May 2019

Published online: 27 May 2019

\section{References}

1. Pugliese A, Beltramo T, Torre D. Emerging and re-emerging viral infections in Europe. Cell Biochem Funct. 2007;25:1-13.

2. Morse SS. Factors in the emergence of infectious disease. Plagues and politics. London: Palgrave Macmillan; 2001. p. 8-26.

3. Sousa CA, Clairouin M, Seixas G, Viveiros B, Novo MT, Silva AC, et al. Ongoing outbreak of dengue type 1 in the Autonomous Region of Madeira, Portugal: preliminary report. Euro Surveill. 2012;17:20333.

4. Gould EA, Gallian P, De Lamballerie X, Charrel RN. First cases of autochthonous dengue fever and chikungunya fever in France: from bad dream to reality! Clin Microbiol Infect. 2010;16:1702-4.

5. Rezza G, Nicoletti L, Angelini R, Romi R, Finarelli AC, Panning M, et al. Infection with chikungunya virus in Italy: an outbreak in a temperate region. Lancet. 2007;370:1840-6.

6. Hubálek Z, Halouzka J. West Nile fever-a reemerging mosquito-borne viral disease in Europe. Emerg Infect Dis. 1999;5:643.

7. de Graaf JA, Reimerink JHJ, Voorn GP, de Vaate EA, bij de Vries A, RockX $B$, et al. First human case of tick-borne encephalitis infection acquired in the Netherlands, July 2016. Euro Surveill. 2016;21:3.

8. Negredo A, de la Calle-Prieto F, Palencia-Herrejón E, Mora-Rillo M, Astray-Mochales J, Sánchez-Seco MP, et al. Autochthonous CrimeanCongo hemorrhagic fever in Spain. New Engl J Med. 2017;377:154-61.

9. Calba C, Guerbois-Galla M, Franke F, Jeannin C, Auzet-Caillaud M, Grard $\mathrm{G}$, et al. Preliminary report of an autochthonous chikungunya outbreak in France, July to September 2017. Euro Surveill. 2017;22:39.

10. Venturi G, Di Luca M, Fortuna C, Remoli ME, Riccardo F, Severini F, et al. Detection of a chikungunya outbreak in central Italy, August to September 2017. Euro Surveill. 2017;22:39.

11. Barrett AD, Monath TP. Epidemiology and ecology of yellow fever virus. Adv Virus Res. 2003;61:291-317.

12. Hanley KA, Monath TP, Weaver SC, Rossi SL, Richman RL, Vasilakis N. Fever versus fever: the role of host and vector susceptibility and interspecific competition in shaping the current and future distributions of the sylvatic cycles of dengue virus and yellow fever virus. Infect Genet Evol. 2013;19:292-311.

13. Volk SM, Chen R, Tsetsarkin KA, Adams AP, Garcia TI, Sall AA, et al. Genome-scale phylogenetic analyses of chikungunya virus reveal independent emergences of recent epidemics and various evolutionary rates. J Virol. 2010;84:6497-504.

14. Vasilakis N, Cardosa J, Hanley KA, Holmes EC, Weaver SC. Fever from the forest: prospects for the continued emergence of sylvatic dengue virus and its impact on public health. Nat Rev Microbiol. 2011;9:532-41.

15. Rogers DJ, Randolph SE. Studying the global distribution of infectious diseases using GIS and RS. Nat Rev Microbiol. 2003;1:231-7.

16. Sunish IP, Reuben R. Factors influencing the abundance of Japanese encephalitis vectors in ricefields in India-I. Abiotic. Med Vet Entomol. 2001;15:381-92.

17. Estrada-Peña A, de la Fuente J. The ecology of ticks and epidemiology of tick-borne viral diseases. Antivir Res. 2014;108:104-28.

18. Guglielmone AA, Robbins RG, Apanaskevich DA, Petney TN, EstradaPeña A, Horak I. The hard ticks of the world. Dordrecht: Springer; 2014

19. Wilson ML, Adler GH, Spielman A. Correlation between abundance of deer and that of the deer tick, Ixodes dammini (Acari: Ixodidae). Ann Entomol Soc Am. 1985;78:172-6.

20. Platonov AE, Rossi G, Karan LS, Mironov KO, Busani L, Rezza G. Does the Japanese encephalitis virus (JEV) represent a threat for human health in Europe? Detection of JEV RNA sequences in birds collected in Italy. Euro Surveill. 2012;17:32.

21. Estrada-Peña A, Zatansever Z, Gargili A, Aktas M, Uzun R, Ergonul O, et al. Modeling the spatial distribution of Crimean-Congo hemorrhagic fever outbreaks in Turkey. Vector Borne Zoonotic Dis. 2007;7:667-78. 
22. Havelaar AH, Van Rosse F, Bucura C, Toetenel MA, Haagsma JA, Kurowicka D, et al. Prioritizing emerging zoonoses in the Netherlands. PLoS ONE. 2010;5:e13965.

23. Bakonyi T, Ferenczi E, Erdélyi K, Kutasi O, Csörgő T, Seidel B, et al. Explosive spread of a neuroinvasive lineage 2 West Nile virus in central Europe, 2008/2009. Vet Microbiol. 2013;165:61-70.

24. Jahfari S, de Vries A, Rijks JM, Van Gucht S, Vennema H, Sprong H, et al. Tick-borne encephalitis virus in ticks and roe deer, the Netherlands. Emerg Infect Dis. 2017;23:1028.

25. Chevalier V, Pepin M, Plee L, Lancelot R. Rift Valley fever-a threat for Europe? Euro Surveill. 2010;15:19506.

26. van den Hurk AF, Ritchie SA, Mackenzie JS. Ecology and geographical expansion of Japanese encephalitis virus. Ann Rev Entomol. 2009;54:17-35.

27. Moutailler S, Krida G, Schaffner F, Vazeille M, Failloux A-B. Potential vectors of Rift Valley fever virus in the Mediterranean region. Vector Borne Zoonotic Dis. 2008;8:749-54

28. Huber K, Jansen S, Leggewie M, Badusche M, Schmidt-Chanasit J, Becker N, et al. Aedes japonicus japonicus (Diptera: Culicidae) from Germany have vector competence for Japan encephalitis virus but are refractory to infection with West Nile virus. Parasitol Res. 2014;113:3195-9.

29. Liberati A, Altman DG, Tetzlaff J, Mulrow C, Gøtzsche PC, loannidis JP, et al. The PRISMA statement for reporting systematic reviews and metaanalyses of studies that evaluate health care interventions: explanation and elaboration. Ann Intern Med. 2009;151:W-65-94.

30. Higgins JP, Green S. Cochrane handbook for systematic reviews of interventions. Wiley Online Library; 2008.

31. Estrada-Peña A, Martínez Avilés M, Muñoz Reoyo MJ. A population model to describe the distribution and seasonal dynamics of the tick Hyalomma marginatum in the Mediterranean Basin. Transbound Emerg Dis. 2011;58:213-23.

32. Estrada-Peña A, Ruiz-Fons F, Acevedo P, Gortazar C, la Fuente J. Factors driving the circulation and possible expansion of Crimean-Congo haemorrhagic fever virus in the western Palearctic. J Appl Microbiol. 2013;114:278-86.

33. Gray JS, Dautel H, Estrada-Peña A, Kahl O, Lindgren E. Effects of climate change on ticks and tick-borne diseases in Europe. Interdiscip Perspect Infect Dis. 2009;2009:593232.

34. Estrada-Peña A, Sánchez N, Estrada-Sánchez A. An assessment of the distribution and spread of the tick Hyalomma marginatum in the western Palearctic under different climate scenarios. Vector Borne Zoonotic Dis. 2012;12:758-68.

35. Estrada-Peña A, Venzal JM. Climate niches of tick species in the Mediterranean region: modeling of occurrence data, distributional constraints, and impact of climate change. J Med Entomol. 2007:44:1130-8.

36. Ouhelli H. Comparative development of Hyalomma marginatum (Koch, 1844), H. detritum (Schulze, 1919), H. anatolicum excavatum (Koch, 1844), H. Iusitanicum (Koch, 1844) and H. dromedarii (Koch, 1844) under laboratory conditions. Acta Parasitol. 1844;1994(39):153-7.

37. Randolph SE, Rogers DJ. Ecology of tick-borne disease and the role of climate. Crimean-Congo hemorrhagic fever. Dordrecht: Springer; 2007. p. 167-86.

38. Aker $\mathrm{S}, \mathrm{AkınCı} \mathrm{H}$, Kılıçoğlu C, Leblebicioglu $\mathrm{H}$. The geographic distribution of cases of Crimean-Congo hemorrhagic fever: Kastamonu, Turkey. Ticks Tick Borne Dis. 2015;6:730-6.

39. Ansari H, Shahbaz B, Izadi S, Zeinali M, Tabatabaee SM, Mahmoodi M, et al. Crimean-Congo hemorrhagic fever and its relationship with climate factors in southeast Iran: a 13-year experience. J Infect Dev Ctries. 2014:8:749-57.

40. Estrada-Peña A, de la Fuente J, Latapia T, Ortega C. The impact of climate trends on a tick affecting public health: a retrospective modeling approach for Hyalomma marginatum (Ixodidae). PLoS ONE. 2015;10:e0125760

41. Mostafavi E, Chinikar S, Bokaei S, Haghdoost A. Temporal modeling of Crimean-Congo hemorrhagic fever in eastern Iran. Int J Infect Dis. 2013;17:e524-8.

42. Vescio FM, Busani L, Mughini-Gras L, Khoury C, Avellis L, Taseva E, et al. Environmental correlates of Crimean-Congo haemorrhagic fever incidence in Bulgaria. BMC Public Health. 2012;12:1.
43. Estrada-Peña A, Vatansever Z, Gargili A, Ergönul Ö. The trend towards habitat fragmentation is the key factor driving the spread of CrimeanCongo haemorrhagic fever. Epidemiol Infect. 2010;138:1194-203.

44. Wilson ML, LeGuenno B, Guillaud M, Desoutter D, Gonzalez J-P, Camicas J-L. Distribution of Crimean-Congo hemorrhagic fever viral antibody in Senegal: environmental and vectorial correlates. Am J Trop Med Hyg. 1990:43:557-66.

45. Sargianou M, Panos G, Tsatsaris A, Gogos C, Papa A. Crimean-Congo hemorrhagic fever: seroprevalence and risk factors among humans in Achaia, western Greece. Int J Infect Dis. 2013;17:e1160-5.

46. Sisman A. Epidemiologic features and risk factors of CrimeanCongo hemorrhagic fever in Samsun province, Turkey. J Epidemiol. 2013;23:95-102.

47. Dogan HM, Cetin I, Egri M. Investigating geographical distribution of Crimean-Congo hemorrhagic fever in tokat county of Turkey. J Biol Sci. 2009;9:217-23.

48. Messina JP, Pigott DM, Golding N, Duda KA, Brownstein JS, Weiss DJ, et al. The global distribution of Crimean-Congo hemorrhagic fever. Trans R Soc Trop Med Hyg. 2015;109:503-13.

49. Estrada-Peña A, Vatansever Z, Gargili A, Buzgan T. An early warning system for Crimean-Congo haemorrhagic fever seasonality in Turkey based on remote sensing technology. Geospat Health. 2007;2:127-35.

50. Hoogstraal $\mathrm{H}$. The epidemiology of tick-borne Crimean-Congo hemorrhagic fever in Asia, Europe, and Africa. J Med Entomol. 1979;15:307-417.

51. Estrada-Peña A, Palomar AM, Santibáñez P, Sánchez N, Habela MA, Portillo A, et al. Crimean-Congo hemorrhagic fever virus in ticks, Southwestern Europe, 2010. Emerg Infect Dis. 2012;18:179-80.

52. Hoch T, Breton E, Josse M, Deniz A, Guven E, Vatansever Z. Identifying main drivers and testing control strategies for CCHFV spread. Exp Appl Acarol. 2016:68:347-59.

53. Knight MM, Norval RAl, Rechav Y. The life cycle of the tick Hyalomma marginatum rufipes Koch (Acarina: Ixodidae) under laboratory conditions. J Parasitol. 1978;64:143-6.

54. Sonenshine DE, Lane RS, Nicholson WL, Mullen G, Durden L. Ticks (Ixodida). In: Medical and veterinary entomology. San Diego, CA: Academic Press; 2002. p. 517-58.

55. Bosch J, Muñoz MJ, Martínez M, De la Torre A, Estrada-Peña A. Vectorborne pathogen spread through ticks on migratory birds: a probabilistic spatial risk model for south-western Europe. Transbound Emerg Dis. 2013;60:403-15.

56. Jameson LJ, Morgan PJ, Medlock JM, Watola G, Vaux AGC. Importation of Hyalomma marginatum, vector of Crimean-Congo haemorrhagic fever virus, into the United Kingdom by migratory birds. Ticks Tick Borne Dis. 2012;3:95-9.

57. Movila A, Alekseev AN, Dubinina HV, Toderas I. Detection of tick-borne pathogens in ticks from migratory birds in the Baltic region of Russia. Med Vet Entomol. 2013;27:113-7.

58. Hornok S, Horváth G. First report of adult Hyalomma marginatum rufipes (vector of Crimean-Congo haemorrhagic fever virus) on cattle under a continental climate in Hungary. Parasites Vectors. 2012;5:170.

59. Nijhof AM, Bodaan C, Postigo M, Nieuwenhuijs H, Opsteegh M, Franssen $L$, et al. Ticks and associated pathogens collected from domestic animals in the Netherlands. Vector Borne Zoonotic Dis. 2007;7:585-96.

60. Kampen H, Poltz W, Hartelt K, Wölfel R, Faulde M. Detection of a questing Hyalomma marginatum marginatum adult female (Acari, Ixodidae) in southern Germany. Exp Appl Acarol. 2007:43:227-31.

61. RIVM. Staat van zoönosen 2012. Bilthoven: Rijksinstituut voor Volksgezondheid en Milieu; 2013.

62. Randolph SE, Miklisova D, Lysy J, Rogers DJ, Labuda M. Incidence from coincidence: patterns of tick infestations on rodents facilitate transmission of tick-borne encephalitis virus. Parasitology. 1999;118:177-86.

63. Labuda M, Randolph SE. Survival strategy of tick-borne encephalitis virus: cellular basis and environmental determinants. Zentralbl Bakteriol. 1999;289:513-24.

64. Randolph SE, Green RM, Peacey MF, Rogers DJ. Seasonal synchrony: the key to tick-borne encephalitis foci identified by satellite data. Parasitology. 2000;121:15-23.

65. Labuda M, Kozuch O, Zuffová E, Elecková E, Hails RS, Nuttall PA. Tickborne encephalitis virus transmission between ticks cofeeding on specific immune natural rodent hosts. Virology. 1997;235:138-43. 
66. Carpi G, Cagnacci F, Neteler M, Rizzoli A. Tick infestation on roe deer in relation to geographic and remotely sensed climatic variables in a tick-borne encephalitis endemic area. Epidemiol Infect. 2008;136:1416-24.

67. Perkins SE, Cattadori IM, Tagliapietra V, Rizzoli AP, Hudson PJ. Empirical evidence for key hosts in persistence of a tick-borne disease. Int J Parasitol. 2003;33:909-17.

68. Cagnacci F, Bolzoni L, Rosà R, Carpi G, Hauffe HC, Valent M, et al. Effects of deer density on tick infestation of rodents and the hazard of tick-borne encephalitis. I: empirical assessment. Int J Parasitol. 2012;42:365-72.

69. Burri C, Bastic V, Maeder G, Patalas E, Gern L. Microclimate and the zoonotic cycle of tick-borne encephalitis virus in Switzerland. J Med Entomol. 2011;48:615-27.

70. Randolph SE, Storey K. Impact of microclimate on immature tickrodent host interactions (Acari: Ixodidae): implications for parasite transmission. J Med Entomol. 1999;36:741-8.

71. Danielová V. Experimental infection of ticks /xodes ricinus with tickborne encephalitis virus under different microclimatic conditions. Folia Parasitol. 1990;37:279-82.

72. Andreassen A, Jore S, Cuber P, Dudman S, Tengs T, Isaksen K, et al. Prevalence of tick-borne encephalitis virus in tick nymphs in relation to climatic factors on the southern coast of Norway. Parasites Vectors. 2012;5:1.

73. Daniel M, Kř́rž B, Danielová V, Valter J, Kott I. Correlation between meteorological factors and tick-borne encephalitis incidence in the Czech Republic. Parasitol Res. 2008;103:97-107.

74. Perret J-L, Guigoz E, Rais O, Gern L. Influence of saturation deficit and temperature on Ixodes ricinus tick questing activity in a Lyme borreliosis-endemic area (Switzerland). Parasitol Res. 2000;86:554-7.

75. Perret J-L, Guerin PM, DiehI PA, Vlimant M, Gern L. Darkness induces mobility, and saturation deficit limits questing duration, in the tick Ixodes ricinus. J Exp Biol. 2003;206:1809-15.

76. Tagliapietra V, Rosà R, Arnoldi D, Cagnacci F, Capelli G, Montarsi F, et al. Saturation deficit and deer density affect questing activity and local abundance of Ixodes ricinus (Acari, Ixodidae) in Italy. Vet Parasitol. 2011;183:114-24

77. Barandika JF, Hurtado A, Juste RA, García-Pérez AL. Seasonal dynamics of Ixodes ricinus in a 3-year period in northern Spain: first survey on the presence of tick-borne encephalitis virus. Vector Borne Zoonotic Dis. 2010;10:1027-35.

78. Cuber P, Andreassen $\AA$, Vainio K, Asman M, Dudman S, Szilman P, et al. Risk of exposure to ticks (Ixodidae) and the prevalence of tick-borne encephalitis virus (TBEV) in ticks in southern Poland. Ticks Tick Borne Dis. 2015;6:356-63.

79. Gilbert L. Altitudinal patterns of tick and host abundance: a potential role for climate change in regulating tick-borne diseases? Oecologia. 2010;162:217-25

80. Tokarevich NK, Tronin AA, Blinova OV, Buzinov RV, Boltenkov VP, Yurasova ED, et al. The impact of climate change on the expansion of Ixodes persulcatus habitat and the incidence of tick-borne encephalitis in the north of European Russia. Glob Health Action. 2011;4:8448.

81. Lindquist L, Vapalahti O. Tick-borne encephalitis. Lancet. 2008;371:1861-71.

82. Danielová V, Kliegrová S, Daniel M, Benes C. Influence of climate warming on tick-borne encephalitis expansion to higher altitudes over the last decade (1997-2006) in the Highland Region (Czech Republic). Cent Eur J Public Health. 2008;16:4

83. Süss J, Klaus C, Gerstengarbe F-W, Werner PC. What makes ticks tick? Climate change, ticks, and tick-borne diseases. J Travel Med. 2008;15:39-45.

84. Randolph SE, Rogers DJ. Fragile transmission cycles of tick-borne encephalitis virus may be disrupted by predicted climate change. Proc R Soc Lond B Biol. 2000;267:1741-4.

85. Randolph SE. Evidence that climate change has caused 'emergence'of tick-borne diseases in Europe? Int J Med Microbiol Suppl. 2004;293:5-15

86. Šumilo D, Asokliene L, Bormane A, Vasilenko V, Golovljova I, Randolph SE. Climate change cannot explain the upsurge of tick-borne encephalitis in the Baltics. PLOS ONE. 2007;2:e500.
87. Korenberg El. Recent epidemiology of tick-borne encephalitis: an effect of climate change? Adv Virus Res. 2009;74:123-44.

88. Lindgren E, Gustafson R. Tick-borne encephalitis in Sweden and climate change. Lancet. 2001;358:16-8.

89. Randolph SE. To what extent has climate change contributed to the recent epidemiology of tick-borne diseases? Vet Parasitol. 2010;167:92-4.

90. Daniel M, Danielová V, Kř́ž B, Kott I. An attempt to elucidate the increased incidence of tick-borne encephalitis and its spread to higher altitudes in the Czech Republic. Int J Med Microbiol Suppl. 2004;293:55-62.

91. Daniel M, Materna J, Hönig V, Metelka L, Danielová V, Harcarik J, et al. Vertical distribution of the tick /xodes ricinus and tick-borne pathogens in the northern Moravian mountains correlated with climate warming (Jeseníky Mts., Czech Republic). Cent Eur J Public Health. 2009;17:139.

92. Godfrey ER, Randolph SE. Economic downturn results in tick-borne disease upsurge. Parasites Vectors. 2011;4:1.

93. Šumilo D, Bormane A, Asokliene L, Vasilenko V, Golovljova I, AvsicZupanc T, et al. Socio-economic factors in the differential upsurge of tick-borne encephalitis in central and eastern Europe. Rev Med Virol. 2008;18:81-95.

94. Hudson PJ, Rizzoli A, Rosa R, Chemini C, Jones LD, Gould EA. Tick-borne encephalitis virus in northern Italy: molecular analysis, relationships with density and seasonal dynamics of Ixodes ricinus. Med Vet Entomol. 2001;15:304-13.

95. Perkins SE, Cattadori IM, Tagliapietra V, Rizzoli AP, Hudson PJ. Localized deer absence leads to tick amplification. Ecology. 2006;87:1981-6.

96. Pugliese A, Rosà R. Effect of host populations on the intensity of ticks and the prevalence of tick-borne pathogens: how to interpret the results of deer exclosure experiments. Parasitology. 2008;135:1531-44.

97. Rizzoli A, Hauffe HC, Tagliapietra V, Neteler M, Rosà R. Forest structure and roe deer abundance predict tick-borne encephalitis risk in Italy. PLOS ONE. 2009;4:e4336.

98. Bolzoni L, Rosà R, Cagnacci F, Rizzoli A. Effect of deer density on tick infestation of rodents and the hazard of tick-borne encephalitis. II: population and infection models. Int J Parasitol. 2012:42:373-81.

99. Zeman P, Januška J. Epizootiologic background of dissimilar distribution of human cases of Lyme borreliosis and tick-borne encephalitis in a joint endemic area. Comp Immunol Microbiol. 1999;22:247-60.

100. Hofmeester TR, Coipan EC, van Wieren SE, Prins HHT, Takken W, Sprong $\mathrm{H}$. Few vertebrate species dominate the Borrelia burgdorferi s.l. life cycle. Environ Res Lett. 2016;11:043001.

101. Anderson RM, May RM. Infectious diseases of humans: dynamics and control. Oxford: Oxford University Press; 1992.

102. Jaenson TG, Hjertqvist M, Bergström T, Lundkvist $\AA$. Why is tick-borne encephalitis increasing? A review of the key factors causing the increasing incidence of human TBE in Sweden. Parasites Vectors. 2012;5:184.

103. Jemeršić $L$, Dežđek D, Brnić D, Prpić J, Janicki Z, Keros T, et al. Detection and genetic characterization of tick-borne encephalitis virus (TBEV) derived from ticks removed from red foxes (Vulpes vulpes) and isolated from spleen samples of red deer (Cervus elaphus) in Croatia. Ticks Tick Borne Dis. 2014;5:7-13.

104. Hasle G. Transport of ixodid ticks and tick-borne pathogens by migratory birds. Front Cell Infect Microbiol. 2013;3:48.

105. Zeimes CB, Olsson GE, Hjertqvist M, Vanwambeke SO. Shaping zoonosis risk: landscape ecology vs. landscape attractiveness for people, the case of tick-borne encephalitis in Sweden. Parasites Vectors. 2014;7:370.

106. Vanwambeke SO, Šumilo D, Bormane A, Lambin EF, Randolph SE. Landscape predictors of tick-borne encephalitis in Latvia: land cover, land use, and land ownership. Vector Borne Zoonotic Dis. 2010;10:497-506.

107. Lindström A, Jaenson TGT. Distribution of the common tick, Ixodes ricinus (Acari: Ixodidae), in different vegetation types in southern Sweden. J Med Entomol. 2003;40:375-8.

108. Uspensky I. Preliminary observations on specific adaptations of exophilic ixodid ticks to forests or open country habitats. Exp Appl Acarol. 2002;28:147-54.

109. Danielová V, Daniel M, Schwarzová L, Materna J, Rudenko N, Golovchenko M, et al. Integration of a tick-borne encephalitis virus and Borrelia burgdorferi sensu lato into mountain ecosystems, following a shift in the altitudinal limit of distribution of their vector, Ixodes ricinus 
(Krkonoše Mountains, Czech Republic). Vector Borne Zoonotic Dis. 2010;10:223-30

110. Haemig PD, Lithner S, Sjöstedt de Luna S, Lundkvist $\AA$, Waldenström $J$, Hansson $L$, et al. Red fox and tick-borne encephalitis (TBE) in humans: can predators influence public health? Scand J Infect Dis. 2008;40:527-32.

111. Gilbert L, Jones LD, Hudson PJ, Gould EA, Reid HW. Role of small mammals in the persistence of louping-ill virus: field survey and tick co-feeding studies. Med Vet Entomol. 2000;14:277-82.

112. Laurenson MK, Norman RA, Gilbert L, Reid HW, Hudson PJ. Identifying disease reservoirs in complex systems: mountain hares as reservoirs of ticks and louping-ill virus, pathogens of red grouse. J Anim Ecol. 2003;72:177-85.

113. Jeffries CL, Mansfield KL, Phipps LP, Wakeley PR, Mearns R, Schock A, et al. Louping ill virus: an endemic tick-borne disease of Great Britain. J Gen Virol. 2014;95:1005-14.

114. Jones LD, Gaunt M, Hails RS, Laurenson K, Hudson PJ, Reid H, et al. Transmission of louping ill virus between infected and uninfected ticks co-feeding on mountain hares. Med Vet Entomol. 1997;11:172-6.

115. Gilbert L, Norman R, Laurenson KM, Reid HW, Hudson PJ. Disease persistance and apparent competition in a three-host community: an empirical and analytical study of large-scale, wild populations. J Anim Ecol. 2001;70:1053-61.

116. Norman R, Ross D, Laurenson MK, Hudson PJ. The role of non-viraemic transmission on the persistence and dynamics of a tick-borne virus Louping ill in red grouse (Lagopus lagopus scoticus) and mountain hares (Lepus timidus). J Math Biol. 2004;48:119-34.

117. Watts EJ, Palmer SCF, Bowman AS, Irvine RJ, Smith A, Travis JMJ. The effect of host movement on viral transmission dynamics in a vectorborne disease system. Parasitology. 2009;136:1221-34.

118. McGuire K, Holmes EC, Gao GF, Reid HW, Gould EA. Tracing the origins of louping ill virus by molecular phylogenetic analysis. J Gen Virol. 1998;79:981-8.

119. Bai L, Morton LC, Liu Q. Climate change and mosquito-borne diseases in China: a review. Glob Health. 2013;9:1.

120. Bi P, Tong S, Donald K, Parton KA, Ni J. Climate variability and transmission of Japanese encephalitis in eastern China. Vector Borne Zoonotic Dis. 2003;3:111-5.

121. Bai Y, Xu Z, Zhang J, Mao D, Luo C, He Y, et al. Regional impact of climate on Japanese encephalitis in areas located near the Three Gorges Dam. PLoS ONE. 2014;9:e84326.

122. Bi P, Zhang Y, Parton KA. Weather variables and Japanese encephalitis in the metropolitan area of Jinan city, China. J Infect. 2007;55:551-6.

123. Lin H, Yang L, Liu Q, Wang T, Hossain SR, Ho SC, et al. Time series analysis of Japanese encephalitis and weather in Linyi City, China. Int J Public Health. 2012;57:289-96.

124. Hsu SM, Yen AMF, Chen THH. The impact of climate on Japanese encephalitis. Epidemiol Infect. 2008;136:980-7.

125. Wang L, Hu W, Magalhaes RJS, Bi P, Ding F, Sun H, et al. The role of environmental factors in the spatial distribution of Japanese encephalitis in mainland China. Environ Int. 2014;73:1-9.

126. Murty US, Rao MS, Arunachalam N. The effects of climatic factors on the distribution and abundance of Japanese encephalitis vectors in Kurnool district of Andhra Pradesh, India. J Vector Dis. 2010;47:26.

127. Borah J, Dutta P, Khan SA, Mahanta J. Association of weather and anthropogenic factors for transmission of Japanese encephalitis in an endemic area of India. EcoHealth. 2013;10:129-36.

128. Miller RH, Masuoka P, Klein TA, Kim H-C, Somer T, Grieco J. Ecological niche modeling to estimate the distribution of Japanese encephalitis virus in Asia. PLoS Negl Trop Dis. 2012;6:e1678.

129. Misra UK, Kalita J. Overview: Japanese encephalitis. Prog Neurobiol. 2010;91:108-20.

130. Impoinvil DE, Solomon T, Schluter WW, Rayamajhi A, Bichha RP, Shakya $\mathrm{G}$, et al. The spatial heterogeneity between Japanese encephalitis incidence distribution and environmental variables in Nepal. PLOS ONE. 2011;6:e22192.

131. Chen M-J, Lin C-Y, Wu Y-T, Wu P-C, Lung S-C, Su H-J. Effects of extreme precipitation to the distribution of infectious diseases in Taiwan, 1994-2008. PLoS ONE. 2012;7:e34651.
132. Su C-L, Yang C-F, Teng H-J, Lu L-C, Lin C, Tsai K-H, et al. Molecular epidemiology of Japanese encephalitis virus in mosquitoes in Taiwan during 2005-2012. PLoS Negl Trop Dis. 2014;8:e3122.

133. van den Hurk AF, Nisbet DJ, Johansen CA, Foley PN, Ritchie SA, Mackenzie JS. Japanese encephalitis on Badu Island, Australia: the first isolation of Japanese encephalitis virus from Culex gelidus in the Australasian region and the role of mosquito host-feeding patterns in virus transmission cycles. Trans R Soc Trop Med Hyg. 2001;95:595-600.

134. Mackenzie JS, Gubler DJ, Petersen LR. Emerging flaviviruses: the spread and resurgence of Japanese encephalitis, West Nile and dengue viruses. Nat Med. 2004;10:598.

135. Ritchie SA, Rochester W. Wind-blown mosquitoes and introduction of Japanese encephalitis into Australia. Emerg Infect Dis. 2001;7:900.

136. Nett RJ, Campbell GL, Reisen WK. Potential for the emergence of Japanese encephalitis virus in California. Vector Borne Zoonotic Dis. 2009:9:511-7.

137. Goddard LB, Roth AE, Reisen WK, Scott TW. Vertical transmission of West Nile virus by three California Culex (Diptera: Culicidae) species. J Med Entomol. 2003;40:743-6.

138. Llopis IV, Tomassone L, Grego E, Serrano E, Mosca A, Vaschetti G, et al. Evaluating the feeding preferences of West Nile virus mosquito vectors using bird-baited traps. Parasites Vectors. 2016;9:479.

139. Vogels CB, Fros JJ, Göertz GP, Pijlman GP, Koenraadt CJ. Vector competence of northern European Culex pipiens biotypes and hybrids for West Nile virus is differentially affected by temperature. Parasites Vectors. 2016;9:393.

140. Fros JJ, Geertsema C, Vogels CB, Roosjen PP, Failloux A-B, Vlak JM, et al. West Nile virus: high transmission rate in north-western European mosquitoes indicates its epidemic potential and warrants increased surveillance. PLoS Negl Trop Dis. 2015;9:e0003956.

141. Muñoz J, Ruiz S, Soriguer R, Alcaide M, Viana DS, Roiz D, et al. Feeding patterns of potential West Nile virus vectors in south-west Spain. PLoS ONE. 2012;7:e39549.

142. Rizzoli A, Bolzoni L, Chadwick EA, Capelli G, Montarsi F, Grisenti M, et al. Understanding West Nile virus ecology in Europe: Culex pipiens host feeding preference in a hotspot of virus emergence. Parasites Vectors. 2015;8:213.

143. Komar N, Langevin S, Hinten S, Nemeth N, Edwards E, Hettler D, et al. Experimental infection of North American birds with the New York 1999 strain of West Nile virus. Emerg Infect Dis. 2003:9:311-22.

144. Nemeth N, Gould D, Bowen R, Komar N. Natural and experimental West Nile virus infection in five raptor species. J Wildl Dis. 2006;42:1-13.

145. Reisen WK, Fang Y, Martinez VM. Avian host and mosquito (Diptera: Culicidae) vector competence determine the efficiency of West Nile and St. Louis encephalitis virus transmission. J Med Entomol. 2005;42:367-75.

146. Dridi $M$, Vangeluwe $D$, Lecollinet $\mathrm{S}$, van den Berg T, Lambrecht B. Experimental infection of Carrion crows (Corvus corone) with two European West Nile virus (WNV) strains. Vet Microbiol. 2013;165:160-6.

147. Kramer LD, Styer LM, Ebel GD. A global perspective on the epidemiology of West Nile virus. Ann Rev Entomol. 2008;53:61-81.

148. Mughini-Gras L, Mulatti P, Severini F, Boccolini D, Romi R, Bongiorno $G$, et al. Ecological niche modelling of potential West Nile virus vector mosquito species and their geographical association with equine epizootics in Italy. EcoHealth. 2014;11:120-32.

149. Paz S, Malkinson D, Green MS, Tsioni G, Papa A, Danis K, et al. Permissive summer temperatures of the 2010 European West Nile fever upsurge. PLOS ONE. 2013:8:e56398.

150. Kilpatrick AM, Meola MA, Moudy RM, Kramer LD. Temperature, viral genetics, and the transmission of West Nile virus by Culex pipiens mosquitoes. PLoS Pathog. 2008;4:e1000092.

151. Cotar Al, Falcuta E, Prioteasa LF, Dinu S, Ceianu CS, Paz S. Transmission dynamics of the West Nile virus in mosquito vector populations under the influence of weather factors in the Danube delta, Romania. EcoHealth. 2016;13:796-807.

152. Chase JM, Knight TM. Drought-induced mosquito outbreaks in wetlands. Ecol Lett. 2003;6:1017-24.

153. Marcantonio M, Rizzoli A, Metz M, Rosà R, Marini G, Chadwick E, et al. Identifying the environmental conditions favouring West Nile virus outbreaks in Europe. PLoS ONE. 2015;10:e0121158.

154. Epstein PR, DeFilippo C. West Nile virus and drought. Glob Change Hum Health. 2001:2:105-7. 
155. Hubalek Z. European experience with the West Nile virus ecology and epidemiology: could it be relevant for the New World? Viral Immunol. 2000;13:415-26.

156. DeGroote JP, Sugumaran R, Brend SM, Tucker BJ, Bartholomay LC. Landscape, demographic, entomological, and climatic associations with human disease incidence of West Nile virus in the state of lowa, USA. Int J Health Geogr. 2008;7:1.

157. Landesman WJ, Allan BF, Langerhans RB, Knight TM, Chase JM. Interannual associations between precipitation and human incidence of West Nile virus in the United States. Vector Borne Zoonotic Dis. 2007;7:337-43.

158. Roehr B. US hit by massive West Nile virus outbreak centred around Texas. BMJ Br Med J. 2012;345:e5633.

159. Bradley CA, Gibbs SE, Altizer S. Urban land use predicts West Nile virus exposure in songbirds. Ecol Appl. 2008;18:1083-92.

160. Dohm DJ, O'Guinn ML, Turell MJ. Effect of environmental temperature on the ability of Culex pipiens (Diptera: Culicidae) to transmit West Nile virus. J Med Entomol. 2002;39:221-5.

161. DeGroote JP, Sugumaran R. National and regional associations between human West Nile virus incidence and demographic, landscape, and land use conditions in the coterminous United States. Vector Borne Zoonotic Dis. 2012;12:657-65.

162. Leblond A, Sandoz A, Lefebvre G, Zeller H, Bicout DJ. Remote sensing-based identification of environmental risk factors associated with West Nile disease in horses in Camargue, France. Prev Vet Med. 2007;79:20-31.

163. Pradier S, Leblond A, Durand B. Land cover, landscape structure, and West Nile virus circulation in southern France. Vector Borne Zoonotic Dis. 2008:8:253-64.

164. Brown HE, Childs JE, Diuk-Wasser MA, Fish D. Ecological factors associated with West Nile virus transmission, northeastern United States. Emerg Infect Dis. 2008;14:1539-45.

165. Bowden SE, Magori K, Drake JM. Regional differences in the association between land cover and West Nile virus disease incidence in humans in the United States. Am J Trop Med Hyg. 2011;84:234-8.

166. Brown H, Diuk-Wasser $M$, Andreadis T, Fish D. Remotely-sensed vegetation indices identify mosquito clusters of West Nile virus vectors in an urban landscape in the northeastern United States. Vector Borne Zoonotic Dis. 2008;8:197-206.

167. Reisen WK, Fang Y, Martinez VM. Effects of temperature on the transmission of West Nile virus by Culex tarsalis (Diptera: Culicidae). J Med Entomol. 2006:43:309-17.

168. Cornel AJ, Jupp PG, Blackburn NK. Environmental temperature on the vector competence of Culex univittatus (Diptera: Culicidae) for West Nile virus. J Med Entomol. 1993;30:449-56.

169. Allan BF, Langerhans RB, Ryberg WA, Landesman WJ, Griffin NW, Katz RS, et al. Ecological correlates of risk and incidence of West Nile virus in the United States. Oecologia. 2009;158:699-708.

170. Ezenwa VO, Godsey MS, King RJ, Guptill SC. Avian diversity and West Nile virus: testing associations between biodiversity and infectious disease risk. Proc R Soc Lond B Biol. 2006;273:109-17.

171. Swaddle JP, Calos SE. Increased avian diversity is associated with lowe incidence of human West Nile infection: observation of the dilution effect. PLOS ONE. 2008;3:e2488.

172. Ostfeld RS, Keesing F. Biodiversity and disease risk: the case of Lyme disease. Conserv Biol. 2000;14:722-8.

173. Loss SR, Hamer GL, Walker ED, Ruiz MO, Goldberg TL, Kitron UD, et al. Avian host community structure and prevalence of West Nile virus in Chicago, Illinois. Oecologia. 2009;159:415-24.

174. Randolph SE, Dobson ADM. Pangloss revisited: a critique of the dilution effect and the biodiversity-buffers-disease paradigm. Parasitology. 2012:139:847-63.

175. Hamer GL, Chaves LF, Anderson TK, Kitron UD, Brawn JD, Ruiz MO, et al. Fine-scale variation in vector host use and force of infection drive localized patterns of West Nile virus transmission. PLoS ONE. 2011;6:e23767.

176. Ferraguti M, Martinez-De la Puente J, Soriguer R, Llorente F, JiménezClavero M, Figuerola J. West Nile virus-neutralizing antibodies in wild birds from southern Spain. Epidemiol Infect. 2016;144:1907-11.

177. Figuerola J, Baouab RE, Soriguer R, Fassi-Fihri O, Llorente F, JimenezClavero MA. West Nile Virus antibodies in wild birds, Morocco, 2008. Emerg Infect Dis. 2009;15:1651-3.
178. Figuerola J, Jiménez-Clavero MA, López G, Rubio C, Soriguer R, GómezTejedor C, et al. Size matters: West Nile Virus neutralizing antibodies in resident and migratory birds in Spain. Vet Microbiol. 2008;132:39-46.

179. Jourdain E, Olsen B, Lundkvist A, Hubálek Z, Šikutová S, Waldenström J, et al. Surveillance for West Nile virus in wild birds from northern Europe. Vector Borne Zoonotic Dis. 2011;11:77-9.

180. López G, Jiménez-Clavero MÁ, Tejedor CG, Soriguer R, Figuerola J. Prevalence of West Nile virus neutralizing antibodies in Spain is related to the behavior of migratory birds. Vector Borne Zoonotic Dis. 2008;8:615-22.

181. López G, Jiménez-Clavero MA, Vázquez A, Soriguer R, Gómez-Tejedor C, Tenorio A, et al. Incidence of West Nile virus in birds arriving in wildlife rehabilitation centers in southern Spain. Vector Borne Zoonotic Dis. 2011;11:285-90

182. Lim SM, Brault AC, van Amerongen G, Bosco-Lauth AM, Romo H, Sewbalaksing VD, et al. Susceptibility of carrion crows to experimental infection with lineage 1 and 2 West Nile viruses. Emerg Infect Dis. 2015;21:1357

183. Koraka P, Barzon L, Martina BEE. West Nile virus infections in (European) birds. J Neuroinfect Dis. 2016;7:2.

184. Allison AB, Mead DG, Gibbs SE, Hoffman DM, Stallknecht DE. West Nile virus viremia in wild rock pigeons. Emerg Infect Dis. 2004;10:2252.

185. Spedicato M, Carmine I, Bellacicco AL, Marruchella G, Marini V, Pisciella $M$, et al. Experimental infection of rock pigeons (Columba livia) with three West Nile virus lineage 1 strains isolated in Italy between 2009 and 2012. Epidemiol Infect. 2016;144:1301-11.

186. Kramer LD, Ebel GD. Dynamics of flavivirus infection in mosquitoes. Adv Virus Res. 2003:60:187-232.

187. Jourdain E, Toussaint Y, Leblond A, Bicout DJ, Sabatier P, Gauthier-Clerc $M$. Bird species potentially involved in introduction, amplification, and spread of West Nile virus in a Mediterranean wetland, the Camargue (Southern France). Vector Borne Zoonotic Dis. 2007;7:15-33.

188. Paştiu Al, Pap PL, Vágási Cl, Niculae M, Páll E, Domşa C, et al. Wild birds in Romania are more exposed to West Nile virus than to Newcastle disease virus. Vector Borne Zoonotic Dis. 2016;16:176-80.

189. Cabre O. West Nile virus in horses, sub-Saharan Africa. Emerg Infect Dis. 2006:12:1958-60.

190. Bellini R, Calzolari M, Mattivi A, Tamba M, Angelini P, Bonilauri P, et al. The experience of West Nile virus integrated surveillance system in the Emilia-Romagna region: five years of implementation, Italy, 2009 to 2013. Euro Surveill. 2014:19:20953.

191. Davies FG, Linthicum KJ, James AD. Rainfall and epizootic Rift Valley fever. Bull World Health Organ. 1985:63:941.

192. Zeller HG, Fontenille D, Traore-Lamizana M, Thiongane Y, Digoutte J-P. Enzootic activity of Rift Valley fever virus in Senegal. Am J Trop Med Hyg. 1997:56:265-72

193. Anyamba A, Linthicum KJ, Tucker CJ. Climate-disease connections: Rift Valley fever in Kenya. Cad Saude Publica. 2001;17:S133-40.

194. Linthicum KJ, Anyamba A, Tucker CJ, Kelley PW, Myers MF, Peters CJ. Climate and satellite indicators to forecast Rift Valley fever epidemics in Kenya. Science. 1999;285:397-400.

195. Wilson ML, Chapman LE, Hall DB, Dykstra EA, Ba K, Zeller HG, et al. Rift Valley fever in rural northern Senegal: human risk factors and potential vectors. Am J Trop Med Hyg. 1994;50:663-75.

196. Anyamba A, Linthicum KJ, Small J, Britch SC, Pak E, de La Rocque S, et al. Prediction, assessment of the Rift Valley fever activity in East and Southern Africa 2006-2008 and possible vector control strategies. Am J Trop Med Hyg. 2010;83:43-51.

197. Balkhy HH, Memish ZA. Rift Valley fever: an uninvited zoonosis in the Arabian Peninsula. Int J Antimicrob Agents. 2003;21:153-7.

198. Bicout DJ, Sabatier P. Mapping Rift Valley fever vectors and prevalence using rainfall variations. Vector Borne Zoonotic Dis. 2004;4:33-42.

199. Elfadil AA, Hasab-Allah KA, Dafa-Allah OM. Factors associated with Rift Valley fever in south-west Saudi Arabia. Rev Sci Tech OIE. 2006:25:1137-45.

200. Caminade C, Ndione J, Diallo M, MacLeod D, Faye O, Ba Y, et al. Rift Valley fever outbreaks in Mauritania and related environmental conditions. Int J Environ Res Public Health. 2014;11:903-18.

201. Clements AC, Pfeiffer DU, Martin V, Pittiglio C, Best N, Thiongane Y. Spatial risk assessment of Rift Valley fever in Senegal. Vector Borne Zoonotic Dis. 2007:7:203-16. 
202. Ropelewski CF, Halpert MS. Global and regional scale precipitation patterns associated with the El Niño/Southern Oscillation. Mon Weather Rev. 1987;115:1606-26.

203. Linthicum KJ, Britch SC, Anyamba A. Rift Valley fever: an emerging mosquito-borne disease. Ann Rev Entomol. 2016;61:395-415.

204. Davies FG, Kilelu E, Linthicum KJ, Pegram RG. Patterns of Rift Valley fever activity in Zambia. Epidemiol Infect. 1992;108:185-91.

205. Glancey MM, Anyamba A, Linthicum KJ. Epidemiologic and environmental risk factors of rift valley fever in southern Africa from 2008 to 2011. Vector Borne Zoonotic Dis. 2015;15:502-11.

206. Abdo-Salem S, Tran A, Grosbois V, Gerbier G, Al-Qadasi M, Saeed K, et al. Can environmental and socioeconomic factors explain the recent emergence of Rift Valley fever in Yemen, 2000-2001? Vector Borne Zoonotic Dis. 2011;11:773-9.

207. Saluzzo JF, Digoutte JP, Chartier C, Martinez D t, Bada R. Focus of Rift Valley fever virus transmission in southern Mauritania. Lancet. 1987;329:504

208. Zeller HG, Akakpo AJ, Ba MM. Rift Valley fever epizootic in small ruminants in southern Mauritania (October 1993): risk of extensive outbreaks. Ann Soc Belg Med Trop. 1995:75:135-40.

209. Hightower A, Kinkade C, Nguku PM, Anyangu A, Mutonga D, Omolo J, et al. Relationship of climate, geography, and geology to the incidence of Rift Valley fever in Kenya during the 2006-2007 outbreak. Am J Trop Med Hyg. 2012;86:373-80.

210. Heinrich N, Saathoff E, Weller N, Clowes P, Kroidl I, Ntinginya E, et al. High seroprevalence of Rift Valley fever and evidence for endemic circulation in Mbeya region, Tanzania, in a cross-sectional study. PLoS Negl Trop Dis. 2012;6:e1557.

211. Métras R, Jewell C, Porphyre T, Thompson PN, Pfeiffer DU, Collins LM, et al. Risk factors associated with Rift Valley fever epidemics in South Africa in 2008-11. Sci Rep. 2015:5:9492.

212. Sindato C, Pfeiffer DU, Karimuribo ED, Mboera LE, Rweyemamu MM, Paweska JT. A spatial analysis of Rift Valley fever virus seropositivity in domestic ruminants in Tanzania. PLoS ONE. 2015;10:e0131873.

213. Sindato C, Karimuribo ED, Pfeiffer DU, Mboera LE, Kivaria F, Dautu G, et al. Spatial and temporal pattern of Rift Valley fever outbreaks in Tanzania; 1930 to 2007. PLoS ONE. 2014;9:e88897.

214. Chevalier V, Rakotondrafara T, Jourdan M, Heraud JM, Andriamanivo $H R$, Durand B, et al. An unexpected recurrent transmission of Rift Valley fever virus in cattle in a temperate and mountainous area of Madagascar. PLoS Negl Trop Dis. 2011;5:e1423.

215. Turell MJ. Effect of environmental temperature on the vector competence of Aedes fowleri for Rift Valley fever virus. Res Virol. 1989;140:147-54.

216. Brubaker JF, Turell MJ. Effect of environmental temperature on the susceptibility of Culex pipiens (Diptera: Culicidae) to Rift Valley fever virus. J Med Entomol. 1998;35:918-21.

217. Rolin Al, Berrang-Ford L, Kulkarni MA. The risk of Rift Valley fever virus introduction and establishment in the United States and European Union. Emerg Microbes Infect. 2013;2:e81.

218. Bird BH, Ksiazek TG, Nichol ST, MacLachlan NJ. Rift Valley fever virus. J Am Vet Med Assoc. 2009;234:883-93.

219. Shoemaker T, Boulianne C, Vincent MJ, Pezzanite L, Al-Qahtani MM, AlMazrou Y, et al. Genetic analysis of viruses associated with emergence of Rift Valley fever in Saudi Arabia and Yemen, 2000-01. Emerg Infect Dis. 2002:8:1415

220. Carroll SA, Reynes J-M, Khristova ML, Andriamandimby SF, Rollin PE, Nichol ST. Genetic evidence for Rift Valley fever outbreaks in
Madagascar resulting from virus introductions from the East African mainland rather than enzootic maintenance. J Virol. 2011;85:6162-7.

221. Chevalier V. Relevance of Rift Valley fever to public health in the European Union. Clin Microbiol Infect. 2013;19:705-8.

222. Altizer S, Ostfeld RS, Johnson PT, Kutz S, Harvell CD. Climate change and infectious diseases: from evidence to a predictive framework. Science. 2013;341:514-9.

223. Purnak T, Selvi NA, Altundag K. Global warming may increase the incidence and geographic range of Crimean-Congo hemorrhagic fever. Med Hypotheses. 2007;68:924-5.

224. Porretta D, Mastrantonio V, Amendolia S, Gaiarsa S, Epis S, Genchi C, et al. Effects of global changes on the climatic niche of the tick Ixodes ricinus inferred by species distribution modelling. Parasites Vectors. 2013;6:271.

225. Vogels CB, Hartemink N, Koenraadt CJ. Modelling West Nile virus transmission risk in Europe: effect of temperature and mosquito biotypes on the basic reproduction number. Sci Rep. 2017;7:5022.

226. Martin V, Chevalier V, Ceccato P, Anyamba A, De Simone L, Lubroth J, et al. The impact of climate change on the epidemiology and control of Rift Valley fever. Rev Sci Tech OIE. 2008:27:413-26.

227. Gould EA, Higgs S. Impact of climate change and other factors on emerging arbovirus diseases. Trans R Soc Trop Med Hyg. 2009;103:109-21.

228. Erlanger TE, Weiss S, Keiser J, Utzinger J, Wiedenmayer K. Past, present, and future of Japanese encephalitis. Emerg Infect Dis. 2009;15:1-7.

229. Hall RJ, Brown LM, Altizer S. Modeling vector-borne disease risk in migratory animals under climate change. Integr Comp Biol. 2016;56:353-64.

230. Estrada-Pena A, Farkas R, Jaenson TG, Madder M, Pascucci I, Tarrés-Call J. Scientific opinion on the role of tick vectors in the epidemiology of Crimean-Congo hemorrhagic fever and African swine fever in Eurasia: EFSA Panel on Animal Health and Welfare. EFSA J. 2010;8:1-156.

231. Pepin M, Bouloy M, Bird BH, Kemp A, Paweska J. Rift Valley fever virus (Bunyaviridae: Phlebovirus): an update on pathogenesis, molecular epidemiology, vectors, diagnostics and prevention. Vet Res. 2010;41:61.

232. Hofhuis A, Reimerink J, Reusken C, Scholte E-J, de Boer A, Takken W, et al. The hidden passenger of lucky bamboo: do imported Aedes albopictus mosquitoes cause dengue virus transmission in the Netherlands? Vector Borne Zoonotic Dis. 2009;9:217-20.

233. Scholte EJ, Den Hartog W, Braks M, Reusken C, Dik M, Hessels A. First report of a North American invasive mosquito species Ochlerotatus atropalpus (Coquillett) in the Netherlands, 2009. Euro Surveill. 2009;14:19400

234. Becker N, Huber K, Pluskota B, Kaiser A. Ochlerotatus japonicus japonicus - a newly established neozoan in Germany and a revised list of the German mosquito fauna. Eur Mosq Bull. 2011;29:88-102.

235. Grandadam $M$, Caro V, Plumet $S$, Thiberge J-M, Souarès $Y$, Failloux $A-B$, et al. Chikungunya virus, southeastern France. Emerg Infect Dis, 2011:17:910.

236. Rappole JH, Hubalek Z. Migratory birds and West Nile virus. J Appl Microbiol. 2003;94:47-58

237. Pfeffer M, Dobler G. Emergence of zoonotic arboviruses by animal trade and migration. Parasites Vectors. 2010;3:35.

\section{Publisher's Note}

Springer Nature remains neutral with regard to jurisdictional claims in published maps and institutional affiliations. 